\title{
Survey sampling in the Global South using Facebook advertisements
}

Leah R. Rosenzweig* ${ }^{1}{ }^{1}$, Parrish Bergquist ${ }^{2}$, Katherine Hoffmann Pham ${ }^{3}$, Francesco Rampazzo $^{4}$, and Matto Mildenberger ${ }^{6}$

${ }^{1}$ Graduate School of Business, Stanford University, 655 Knight Way, Stanford, CA

94305. Email: lrosenzw@stanford.edu

${ }^{2}$ McCourt School of Public Policy, Georgetown University, 37th and O Streets NW

Old North Building Washington, DC 20057. Email: pb968@georgetown.edu

${ }^{3}$ Stern School of Business, New York University, 44 West 4th Street, New York, NY 10033. Email: khof @nyu.edu

${ }^{4}$ Saïd Business School and Leverhulme Centre for Demographic Science, University of Oxford, Park End St, Oxford OX1 1HP, UK. Email:

francesco.rampazzo@sbs.ox.ac.uk

${ }^{6}$ Department of Political Science, University of California Santa Barbara, Ellison Hall 3834, Santa Barbara, CA 93106. Email: mildenberger@ucsb.edu

October 15, 2020

*(r) Order of the authors was randomized. 


\begin{abstract}
Survey research in the Global South traditionally requires large budgets and lengthy fieldwork, for which researchers hire local enumerators to conduct face-to-face surveys with respondents. However, much of the world's population is now digitally accessible, offering an opportunity for researchers with limited budgets and those seeking to study settings where in-person contact is impossible, such as natural disasters, violent conflicts, and pandemics. In this paper, we evaluate whether Facebook advertising can be used to cost-effectively generate representative survey samples in the Global South. We introduce a framework for evaluating quality in Facebook survey samples, highlighting key trade-offs for researchers considering the platform. We then quota-sample respondents in two countries: Mexico $(n=5,168)$ and Kenya $(n=1,452)$ to evaluate how well these samples perform on a diverse set of survey indicators related to both internal and external validity. We find that while the Facebook platform can quickly and cheaply recruit respondents, these samples tend to be more male, more educated, and more urban than the overall national populations. Applying post-stratification weighting after oversampling key demographic variables ameliorates, but does not fully overcome, these initial sample imbalances. Our analysis demonstrates the considerable potential of Facebook advertisements to cost-effectively conduct research in diverse global settings.
\end{abstract}

\title{
1 Introduction
}

Survey research in the Global South traditionally requires large budgets and lengthy fieldwork, for which researchers hire local enumerators to conduct face-to-face surveys with respondents. Historically, there have been few alternatives to in-person recruitment due to poor electricity coverage and limits to phone and internet connectivity. However, today much of the world's population is digitally accessible. An estimated $67 \%$ of the world's population has a mobile phone subscription, and approximately $49 \%$ of the world's population has access to mobile internet [11, 28]. This growing connectivity represents an opportunity for researchers with limited budgets and those seeking to study settings where the traditional resource-intensive, in-person contact model of research is impossible, such as natural disasters, violent conflicts, and pandemics. Now more than ever, as in-person research has come to a stand-still due to the COVID-19 crisis, social science researchers require creative ways to recruit respondents remotely. This paper describes one such method of recruiting online samples that can complement traditional on-the-ground fieldwork and data collection.

This paper explores the opportunity that Facebook's advertising platform presents to recruit respondents online in the Global South. According to Facebook, the company had 2.45 billion monthly active users in September 2019 [9], nearly a third of the global population. For this same month, the company reported an average of 1.62 billion daily active users [9], about $20 \%$ of all living humans. Facebook advertising thus offers researchers unparalleled access to nationally, culturally, and demographically diverse populations around the world. Furthermore, Facebook offers efficiency in terms of time and money compared to other modes of online survey recruitment. It also enables micro-targeting, allowing scholars to recruit samples from specific, difficult-to-reach sub-populations such as would-be first-time voters or residents of a particular locality.

A recent literature has begun to explore and evaluate Facebook as a platform for recruiting survey samples. Facebook has been used to target respondents from demographic groups with specific characteristics or behaviors, including young smokers [26, 17]; political activists in Thailand and Germany [16]; Polish migrants in Austria, Ireland, Switzerland, and the UK [25]; and primary voters in local elections [12]. Facebook has also been used to construct a panel of survey respondents from East Africa [27], to recruit experimental subjects in Brazil [30], to deliver and test political advertisements [7, 29], and to conduct surveys during the COVID-19 pandemic $[10,5]$.

To date, many of these studies emphasize the utility of Facebook advertising for recruiting specific target populations that are of theoretical interest to a given research question. However, as Boas, Christenson, and Glick [6] demonstrate in India and the United States, Facebook's high penetration rate and the diversity of its user base make the platform an attractive opportunity for recruiting 
nationally representative samples. Zhang et al. [36] use targeted Facebook advertising to cost-effectively recover approximately nationally representative estimates of public opinion in the United States. In this paper we ask: is this kind of quota-based sampling method also successful in the Global South?

We extend Zhang et al.'s work in two primary directions. First, we introduce a framework for evaluating quality in Facebook survey samples, highlighting key tradeoffs in order to guide researchers who are considering running surveys on the platform. Second, we provide data from two countries, one in Latin America and the other in sub-Saharan Africa, to evaluate the representativeness of Facebookrecruited samples in the Global South. Due to lower levels of internet access, literacy, and Facebook marketing investment in these regions, it is not clear that findings from US-based studies will generalize to other national contexts. We evaluate this question empirically.

We assess cost-quality tradeoffs involved in using Facebook to quota-sample respondents in Mexico $(\mathrm{n}=5,168)$ and Kenya $(\mathrm{n}=1,452)$. We evaluate how well these samples perform on quality indicators related to both internal and external validity. We evaluate representativeness along two different respondent dimensions - demographics and opinions - both before and after the application of weights designed to correct imbalances in the sample. We also describe some of the practical considerations involved in Facebook sampling. We conclude with a discussion of the tradeoffs between the quality of Facebook and other samples, and the costs associated with each sampling mode.

We find that while the Facebook platform enables researchers to quickly and cheaply recruit respondents, these samples tend to be more male, more educated, and more urban than the national populations in Mexico and Kenya. Quota-based sampling and weighting help to ameliorate, but do not fully overcome, imbalances in the samples. In terms of political attitudes and engagement, our samples exhibit some similarities to, and some divergence from, the respective national populations. Taken together, these findings suggest that the value of Facebook samples will depend on the type of research question asked and the target population of interest. Facebook samples should be assessed for representativeness along multiple dimensions, and against various population benchmarks.

\section{Assessing quality in public opinion samples}

\subsection{Defining quality}

We begin by developing a definition of survey quality which builds upon a growing body of research assessing cost-quality tradeoffs in public opinion research. Scholars have assessed the quality of samples recruited through Amazon's Mechanical Turk (MTurk) [3, 13], Prime Panels [21], Lucid Fulcrum Exchange [8], Google Consumer Surveys [31], and Facebook Advertising [19, 16, 6, 36]. Building on this work, we assess quality using the canonical paradigm of internal and external validity.

\subsection{Internal Validity}

Internal validity refers to whether a study accurately captures the phenomena it aims to measure. In our setting, the core internal validity questions are: Is the survey able to target respondents with the characteristics of interest? Do the survey responses actually come from the population targeted by the survey? Are the responses thoughtful and accurate?

To answer these questions, we first assess whether we successfully recruit individuals whose Facebookreported characteristics match the criteria in our sampling strata, such as gender, location, and age. Next, we ask whether Facebook correctly identifies these respondents. To do this, we compare individuals' self-reported demographic and geographic characteristics with the characteristics targeted by the Facebook ad which recruited each individual. ${ }^{1}$ Finally, other characteristics like respondent atten-

\footnotetext{
${ }^{1}$ As we discuss in further detail below, we have these individual-level, Facebook-reported geographic and demographic data because we know from which of our targeted ads each individual was recruited. The platform targets individuals based on a match between a) the demographic and geographic characteristics defined in our advertising strata and b) the individuals' demographic characteristics and geographic location as measured by Facebook.
} 
tiveness have implications for the validity of a survey's descriptive findings. We thus assess how our Facebook sample performs on survey completion times and standard measures of respondent attention.

\subsection{External validity}

External validity refers to whether a study's conclusions can be generalized to a broader population of interest. In our case, key questions include: Is the survey sample drawn using Facebook ads representative of the Facebook population? Is the survey sample drawn using Facebook ads representative of the national adult populations in our target countries?

In order for responses collected via Facebook to generalize to broader populations, three assumptions should be met: positivity, ignorability, and independence. The first two of these are drawn from Zhang et al. [36], while the third is introduced here. All researchers choosing a survey mode face tradeoffs, and most online or phone surveys, as well as many in-person surveys, suffer from violations of these assumptions. Our goal is to clearly document these tradeoffs in the context of the Facebook platform.

\subsubsection{Positivity}

In order to construct externally valid inferences by reweighting our survey responses, we must first assume that, for each combination of sampling strata and observable characteristics used in the weighting, there is a non-zero probability that the associated respondents will take the survey. Borrowing from the causal inference framework, we refer to this assumption as the positivity assumption.

Formally, define $R_{i}$ as an indicator of whether member $i$ of the population takes the survey; $\mathbf{D}_{i}$ as the vector of respondent $i$ 's characteristics that researchers used to construct strata for quota sampling; and $\mathbf{X}_{i}$ as the vector of respondent $i$ 's characteristics that are not used to construct strata but that are measured in the survey and used for weighting. Then, the positivity assumption states that:

\section{Assumption 1 Positivity}

$$
\operatorname{Pr}\left(R_{i}=1 \mid \mathbf{D}_{i}=\mathbf{d}_{i}, \mathbf{X}_{i}=\mathbf{x}_{i}\right) \quad>0, \quad \forall \quad \mathbf{d}_{i} \in \operatorname{Supp}\left(\mathbf{D}_{i}\right), \mathbf{x}_{i} \in \operatorname{Supp}\left(\mathbf{X}_{i}\right)
$$

A violation of the positivity assumption would occur if there are certain sample strata that Facebook is unable to fill. A violation of the positivity assumption would also arise if there are some groups of individuals who are not on Facebook at all, making it impossible to recruit them into our sample. In practice, for efforts to collect nationally representative data, this assumption is almost always violated since Facebook's penetration is less than 100 percent. The likelihood of violations varies across countries, since internet and Facebook use differ by country (see Figure 1). ${ }^{2}$

\subsubsection{Ignorability}

Second, we must assume that conditional on strata and observed respondent characteristics, respondents who take the survey are, in expectation, identical to those who did not take the survey. Again following the causal inference framework, we refer to this assumption as ignorability. This is equivalent to assuming that those not included in the sample are Missing at Random (MAR).

Formally, define $Y_{i}$ as person $i$ 's response to a survey question. Then, the ignorability assumption states:

Assumption 2 Ignorability

$$
Y_{i} \Perp R_{i} \mid \mathbf{D}_{i}=\mathbf{d}_{i}, \quad \mathbf{X}_{i}=\mathbf{x}_{i}, \quad \forall \mathbf{d}_{i} \in \operatorname{Supp}\left(\mathbf{D}_{i}\right), \quad \mathbf{x}_{i} \in \operatorname{Supp}\left(\mathbf{X}_{i}\right)
$$

${ }^{2}$ Facebook penetration rates should be less than $100 \%$. The data shown in Figure 1 are biased due to 1 ) undercounting of national population estimates and 2) fake and duplicated Facebook accounts. Facebook suggests that in 2019, $11 \%$ of accounts on its platform were duplicates. This percentage is higher in South East Asia [34]. 


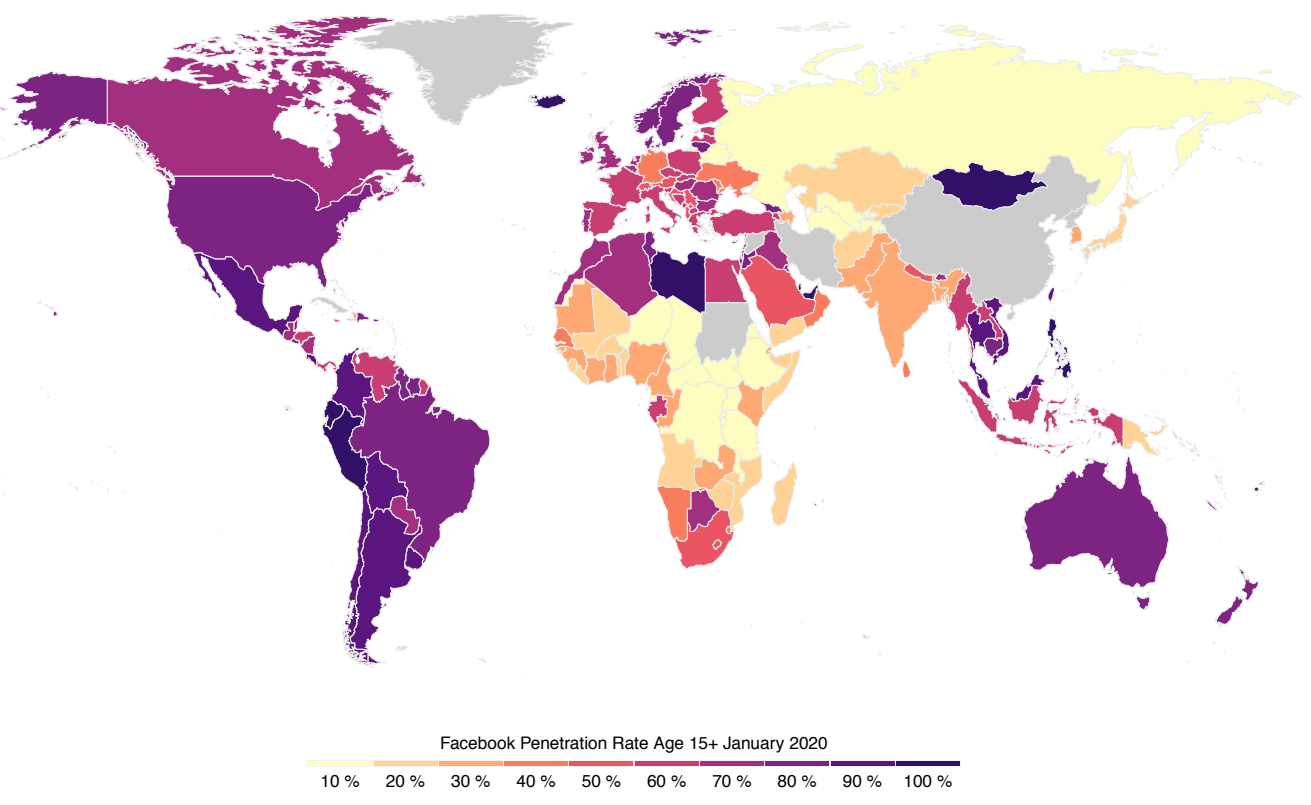

Figure 1: Facebook penetration rates among users age 15 years and older around the world. The rate is computed as of January 2020 with Facebook and United Nations data [33, 32]. The Facebook data is courtesy of Palotti et al. [24].

A violation of the ignorability assumption would occur if Facebook respondents from within a stratum are significantly different from those in the stratum who do not respond. This challenge arises frequently in surveys, since those who select into responding often have more time, or are more pro-social, than those who refuse the survey. Particularly in the Global South, we might worry that wealthier individuals are more likely to take the survey if they have easier access to the internet or are better able to navigate the digital survey interface. Survey incentives might shape such biases: while offering survey incentives may encourage greater participation from low-income users who pay to access the internet, incentives may motivate these low-income users more than others. We provided such incentives for respondents in Kenya, but not in Mexico; future work could directly compare samples recruited in the same country with and without incentives.

Researchers using Facebook for sample recruitment face one additional concern that is particular to Facebook: the ad platform's targeting algorithm may exacerbate selection bias. Subject to a set of targeting constraints, Facebook deliberately serves ads to those who are most likely to click and to respond. Our demographic and geographic quotas help to reduce this bias. Still, they are unlikely to fully erase the problem, since the internal workings of Facebook's algorithm are opaque and may make targeting decisions using variables that we did not include in the stratification design. Encouragingly, the quotas for each of our ad targeting strata were generally too small for Facebook's algorithm to fully optimize ad delivery. ${ }^{3}$ For researchers running large-scale surveys over a longer time horizon, it is worth noting that the algorithm may find a progressively less representative sample within a stratum over time.

\footnotetext{
${ }^{3}$ Facebook typically reported that the algorithm was still in the training phase, suggesting that its targeting algorithm was not functioning optimally.
} 


\subsubsection{Corollary: Independence}

Finally, within each stratum, we assume that each respondent is independently sampled from the broader population of individuals in the stratum. This means that the response rates of two individuals within a stratum should not be correlated with each other, relative to the broader population of the stratum. Similarly, response rates from individuals in one stratum should not be correlated with the response rates of individuals in another stratum. More formally:

Assumption 3 Independence

$$
\begin{aligned}
R_{i}\left|\mathbf{D}_{i}=\mathbf{d}_{i}, \mathbf{X}_{i}=\mathbf{x}_{i} \quad \Perp \quad R_{j}\right| \mathbf{D}_{j}=\mathbf{d}_{j}, \mathbf{X}_{j}=\mathbf{x}_{j}, \\
\forall \mathbf{d}_{i} \in \operatorname{Supp}\left(\mathbf{D}_{i}\right), \mathbf{d}_{j} \in \operatorname{Supp}\left(\mathbf{D}_{j}\right), \quad \mathbf{x}_{i} \in \operatorname{Supp}\left(\mathbf{X}_{i}\right), \mathbf{x}_{j} \in \operatorname{Supp}\left(\mathbf{X}_{j}\right)
\end{aligned}
$$

Most survey re-weighting approaches assume an independent and identically distributed (i.i.d.) random sample from each stratum of interest, but link sharing on Facebook may introduce violations of this assumption. If respondents share the survey link, individuals may come into a survey by invitation or recruitment within a smaller social network. For example, women aged 25-30 might share the link with other friends in their age cohort (leading to non-independent response rates within the stratum), or they may share the link with husbands aged 25-30 (leading to correlated response rates across strata). Sharing may be particularly likely when there are generous rewards for survey completion. If appropriate safeguards are not in place, we might also be concerned that the same individuals attempt to complete the survey repeatedly in an effort to secure multiple units of compensation. ${ }^{4}$

Note that this independence violation can be seen as a specific violation of the ignorability assumption. Network-recruited respondents share an unobserved common characteristic (their location in the network) which is correlated with their representation in the sample.

\section{Procedures and Data Collection}

\subsection{Case selection}

We selected Mexico and Kenya as typical cases for Facebook sampling in the Global South for several reasons. First, Facebook penetration in both countries is about average for their respective regions. Comparisons to Facebook penetration in South Africa (45\%), Nigeria (22\%), and Tanzania (13\%) show that Kenya (25\%) is neither a best nor a worst case. Facebook usage in Mexico (87\%) is also similar to other countries in its region, such as Brazil (72\%) and Argentina (83\%). ${ }^{5}$ Second, both countries have average levels of mobile phone use for their respective regions. Finally, adult literacy is about $82 \%$ and $95 \%$ in Kenya and Mexico, respectively, meaning that a majority of citizens would be able to read and potentially self administer an online survey [35].

\subsection{Quota Sampling}

To recruit respondents in Kenya and Mexico, we use a quota sampling design inspired by well-respected, in-person representative surveys in these countries (Latin American Public Opinion Project and Afrobarometer). Our geographic targeting approach was modeled on the geographic stratification approaches used by these surveys. Within each geographic stratum, we designed target cells based on the demographic characteristics used in our benchmark in-person surveys: gender and (in Mexico) age. We attempted to correct observed or expected imbalances by targeting additional respondents within underrepresented education (in Mexico and Kenya) and age (in Kenya) categories.

\footnotetext{
${ }^{4}$ To address these concerns, we only paid survey incentives to unique phone numbers, unless respondents provided a reason why the same number was used twice. We also changed the survey link frequently, so that link sharing was only possible in the short term.

${ }^{5}$ We calculated these figures based on the number of users per country that Facebook reports [2] and the population figures for individuals age 15 years and older in each country available from the UN [33, 32].
} 
Facebook allows for two different types of geographic targeting. Researchers can directly target audiences by providing an address or a latitude and longitude of interest, as well as a radius defining the catchment area. In Kenya, we targeted primarily based on latitude and longitude, although we supplemented this sample with respondents from older and low-education groups recruited at the province level. Alternatively, researchers can use Facebook's predefined geographic entities, which typically consist of neighborhoods, cities, or national administrative units (e.g. states). In Mexico, we targeted respondents according to these predefined geographic entities. We are therefore able to examine the viability of both approaches to geographic targeting. Below, we summarize our sampling strategies. Section 2 of the Supplementary Information includes further details about the approach taken in both countries, along with an extended discussion of the constraints and opportunities embedded within Facebook's advertising platform.

Table 1: Comparison of the data collected in Mexico and Kenya

\begin{tabular}{|c|c|c|}
\hline & Mexico & Kenya \\
\hline Demographic targeting & Gender, age, (education)* & Gender, (age, education)* \\
\hline Geographic targeting & Administrative unit & $\begin{array}{l}\text { Grouped Afrobarometer clus- } \\
\text { ters }\end{array}$ \\
\hline Field dates & August 17-18, 2019 & September 21-29, 2019 \\
\hline Incentives & No & Yes $(\sim \$ 0.50)$ \\
\hline Comparison & $\begin{array}{l}2015 \text { Census } \\
2019 \text { Americas Barometer }\end{array}$ & $\begin{array}{l}2019 \text { Census } \\
2016 \text { AfroBarometer }\end{array}$ \\
\hline Question types & $\begin{array}{l}\text { Demographics, political party } \\
\text { affiliation, climate change }\end{array}$ & $\begin{array}{l}\text { Demographics, mobility, po- } \\
\text { litical attitudes, social media } \\
\text { use, fertility, household as- } \\
\text { sets, behavioral experiment } \\
60\end{array}$ \\
\hline N. quota sampling cells & 128 & 66 \\
\hline N. respondents & 5,168 & 1,452 \\
\hline
\end{tabular}

\subsubsection{Mexico: sampling by administrative unit}

To draw a nationally representative sample of Mexican residents, we targeted Facebook users by age, gender, and geographic location. In order to gauge baseline interest in taking the survey without compensation, we did not compensate respondents for their participation in the short survey. Our geographic sampling protocol mirrors the procedure used by the LAPOP [20] (LAPOP) to sample within small, medium, and large municipalities. ${ }^{6}$ Within these geographic strata, we further stratified respondents based on gender and age categories. After this initial data collection, we found that our sample underrepresented Mexicans whose highest level of education completed was high school or less. To correct this imbalance, we conducted a second round of data collection in which we targeted respondents in each of our previously constructed geographic-demographic strata who had no more than a high school education. After collecting this low-education sample and dropping individuals with self-reported ages under $18(\mathrm{n}=165)$; those who did not report their age, gender, geographic location, or education level; and one individual without a recorded stratum, ${ }^{7}$ our sample contained 5,168 individuals.

\footnotetext{
${ }^{6}$ LAPOP collects a sample that is stratified by four geographic regions, size of municipality $(100,000+$ inhabitants; 25,000-100,000 inhabitants, and less than 25,000 inhabitants), and urban and rural areas within municipalities.

${ }^{7}$ This likely occurred because the user inadvertently modified the Facebook Ad url which contained quota-related data.
} 


\subsubsection{Kenya: sampling by geolocation}

In Kenya, we targeted ads according to gender (male, female) and geography. Respondents were compensated with 50 Kenyan Shillings' $(\sim \$ 0.50)$ worth of airtime sent to their phones. ${ }^{8}$ The Facebook ad clearly stated that this was the incentive for participation. We used a geographic quota sampling approach to mimic the Afrobarometer sampling strategy. We began by obtaining a list of 227 site locations from the 2016 Afrobarometer survey and identified those with more than 1,000 monthly active Facebook users for both genders. We clustered these site locations into 25 groups and targeted audiences within 12 miles of the centroid of each cluster. Within these clusters, we stratified respondents by gender. Anticipating that we would have a hard time reaching less educated and older respondents, we also created two ads in each of the eight provinces (excluding the capital of each province) ${ }^{9}$ of Kenya to target users 32 years and older, and users with an "unspecified" education level. ${ }^{10}$ After removing respondents who completed the survey in less than five minutes, respondents who did not complete the survey, duplicate entries from respondents who took the survey more than once, and those who did not report an age, we were left with a sample of 1,452 respondents.

\subsection{Survey Instruments}

To direct respondents to the surveys, we created Facebook pages representing our survey campaigns, and placed ads from these pages to target people within the sampling strata described. After clicking on the Facebook ad, respondents were sent to a survey hosted on Qualtrics. For Kenyan respondents, the first survey question asked respondents to choose from one of five possible languages (English, Kiswahili, Kikuyu, Luo, and Somali) in which to take the survey. For Mexican respondents the survey was administered in Spanish. Upon completing the survey, respondents were directed to a thank-you page with an embedded Facebook "Pixel" which allowed Facebook to identify the users who clicked on the ad and completed the survey.

We designed both the Mexico and the Kenya surveys to collect information on demographics and attitudes that we could compare to each country's census and to other nationally representative surveys fielded around the same time. The survey used in Mexico replicated certain questions from the Mexican Census and the LAPOP survey, fielded in early 2019 [20]. The survey used in Kenya replicated questions from the Kenyan Census and the Afrobarometer survey. It was fielded immediately following the 2019 census and concurrent with the 2019 Afrobarometer. ${ }^{11}$ Full copies of our surveys are presented in the Supplementary Information (Section 4).

\subsection{Poststratification adjustments}

For both samples, we then used iterative proportional fitting, or raking, to create weights for all respondents according to the distribution of the national populations across gender, education, age cohort, and geography. ${ }^{12}$ We created the weights using the rake function in the survey package in $\mathrm{R}$ [22], which iterates to proportionally fit weights based on the marginal distributions of demographic

\footnotetext{
8 "Airtime" is mobile credit that can be used for calling or data.

${ }^{9}$ Kenya no longer uses provinces as the country's primary geographic unit, which is now the county. However, provinces were the administrative units available on the Facebook targeting interface.

${ }^{10}$ Since Facebook's education levels mimic the US system, the available targeting levels do not correspond to those in Kenya. We guessed that those who did not finish primary school (or who otherwise had little schooling) might have left their education blank or Facebook would be unable to impute their education level, and therefore would be assigned to this category. Our understanding from conversations with a Facebook marketing advisor is that Facebook estimates education using a range of data sources including a user's location, websites visited, pages liked, and information posted on the user's profile page.

${ }^{11}$ Note: the 2019 Afrobarometer data are not yet available, so we currently compare our sample to the 2016 Afrobarometer.

${ }^{12} \mathrm{~A}$ comparison of weighting procedures suggests that choosing appropriate weighting variables is more important than using a more complex statistical procedure, and that raking works just as well as more complex methods to reduce bias $[23]$.
} 
variables of interest. We weighted respondents based on age, gender, education, and geography. Full details are included in Supplementary Section 5.

\section{Internal Validity}

Below, we assess three dimensions of internal validity as they apply to Facebook survey data from Kenya and Mexico. First, we ask whether it was feasible to target our respondents of interest and to recruit enough survey participants to fill each sampling cell. Second, we evaluate whether the respondents recruited into each cell reported demographic characteristics and geographic locations that matched the demographic and geographic characteristics targeted by the Facebook ad they received. Finally, conditional on having been recruited, we check whether respondents were attentive to the survey and honest in their responses.

\subsection{Does Facebook allow us to target the respondents of interest?}

A first-order internal validity question is whether Facebook allows us to target and fill the strata of interest. As a first check, we examine our success in targeting individuals in each geographic area of interest. In Mexico, we find a good distribution of responses. Using only self-reported residential data, in each of our 128 target cells we collected responses from between 17 and 77 individuals, with a median of 41 individuals. $^{13}$

In Kenya, we were less successful in filling our 66 strata. The quota targets for each stratum were set according to the Afrobarometer weights associated with each stratum's geolocation, which are based on population. ${ }^{14}$ Therefore, the number of respondents targeted per stratum ranged from 4 167. Ultimately, we filled 17 of our 66 target strata; the strata that fell short were missing a median of three respondents. ${ }^{15}$ Two main factors contributed to the failure to fill some strata. First, we manually closed several of our survey strata because the advertising cost per completed survey was too high $(\$ 5$ or more per respondent). Second, because of concern about viral sharing and completions of surveys that were not recorded by Facebook, we typically ended survey ads slightly before the corresponding stratum was filled.

\subsection{Does Facebook correctly identify respondents?}

We next assess whether Facebook appropriately directed us to individuals who matched the criteria in each particular quota cell. Since we recorded the ad on which each respondent clicked in order to enter our survey, we can compare self-reported demographics with those used by Facebook's platform. Table 2 provides the percentage of people in each category for which self-reported and Facebook-targeted characteristics match.

Facebook's targeting was remarkably accurate in identifying respondents by gender in both countries, mostly accurate in identifying respondents by geography in both countries and age in Mexico. Targeting by age was problematic in Kenya, as was targeting by education in both countries. A detailed discussion of the match between Facebook-reported and self-reported respondent characteristics is included in Supplementary Section 1.1. Here we discuss age and education targeting, since these aroused greatest concern for internal validity.

Targeting by education was imprecise in both countries, and targeting by age proved imperfect in Kenya. When we targeted ads to Kenyans 32 years and older, only $47 \%$ of respondents who reached our survey from these ads were indeed 32 years old or older. The ages of these respondents ranged from 19 to 48 years old, with a mean of 31 years. Regarding education, in our second round of data collection in Mexico we targeted respondents with a high school degree and lower levels of education. Only

\footnotetext{
${ }^{13}$ 1st quartile: 33 , 3rd quartile: 46.

${ }^{14}$ For the province-level oversampling of older and less-educated respondents, we set a quota of 5 respondents per stratum.

${ }^{15}$ Min: 1, max: 52 .
} 
Table 2: Accuracy of Facebook targeting, as defined by the percent match between Facebook- and self-reported data

\begin{tabular}{|l|c|c|}
\hline Characteristic & Mexico & Kenya \\
\hline Age & 87 & $47^{*}$ \\
Gender & 99 & 90 \\
Location & 67 & 64 \\
Education level & 30 & $13^{\ddagger}$ \\
\hline
\end{tabular}

* This reflects the proportion of respondents who were at least 32 years old, given that they responded to an ad targeting this age group specifically. ${ }^{\ddagger}$ This reflects the proportion of respondents who reported some secondary school or less, given that they responded to an ad targeting respondents with an "unspecified" level of education.

$30 \%$ of the respondents who reached our survey through these ads self-reported education levels that matched Facebook's categorization. However, $43 \%$ of the individuals in the low-education targeted group reported their highest level of education as "Bachillerato/ Profesional Técnico/ Media Superior." Facebook may consider these technical school degrees — which overlap with the type of schooling that U.S. residents might call "high school" - equivalent to high school. If this is the case, then Facebook correctly categorized $73 \%$ of the respondents in this group. The ambiguity in Facebook's category definitions for this group illustrates one challenge of using a cross-national platform with universal targeting categories.

In Kenya we targeted Facebook users who did not specify their educational attainment in an attempt to recruit less educated Kenyans. ${ }^{16}$ The 31 respondents recruited by these ads did have slightly lower levels of education, on average, than the rest of our sample. ${ }^{17}$ However, this was not an exact targeting strategy: only $13 \%$ of the sample recruited from ads targeting those with an unspecified education level self-reported having some secondary school or less, compared to $3 \%$ of respondents recruited from all other ads.

\subsection{Are respondents paying attention to survey questions?}

We assess a second dimension of internal validity by examining the quality of responses provided by individuals recruited through Facebook. We first assess response times, since rushing through a survey is a standard indicator of low-quality responses. In Mexico, respondents took between 2 minutes and 10 hours to complete the survey, with a median of 6 minutes. The survey consisted of 23 questions, and 5-8 minutes is a reasonable amount of time to complete a survey of this length. In Kenya, respondents took between 4 minutes and 140 hours to complete the survey, with a median time of 24 minutes. The survey consisted of 60 questions covering a broader range of topics, so it is unsurprising that average completion times were longer. Again, 20-30 minutes is a reasonable amount of time in which to complete a survey of this length. ${ }^{18}$

Another concern with online surveys is that even if respondents take time to complete the survey, they simply click through without reading and answering questions honestly. This is particularly worrisome when respondents are paid for their participation and time, as was the case in Kenya. In Kenya we included two questions in the survey to check whether respondents were paying attention. ${ }^{19}$ The questions varied in their difficulty, and pass rates varied accordingly: $98 \%$ of respondents answered

\footnotetext{
${ }^{16}$ Among the population of Facebook users 18 years and older in Kenya, Facebook reports an "unspecified" education level for $40 \%$ of people.

${ }^{17}$ For example, $10 \%$ reported that primary school, informal school, or no school was the highest level of education they had attained, compared with $2 \%$ in the rest of our sample. Only $23 \%$ of this subsample reported completing university or post-graduate education, relative to $34 \%$ in the rest of our sample.

${ }^{18}$ By examining the operating system respondents used to complete the survey, we estimate that $96 \%$ of respondents in Kenya took the survey on their phone. Linux and Windows operating systems were coded as computers, while Android and iPhone were coded as mobile devices.

${ }^{19} \mathrm{~A}$ full description of both attention checks is included in Section 2.2.1 of the Supplementary Information.
} 
the "easy" attention check question correctly, whereas only $54 \%$ of respondents passed the more taxing attention check. Based on these findings, we recommend that researchers include multiple attention checks of varying difficulty [4], to ensure that the questions are testing attention and honesty rather than respondent comprehension or sophistication.

\section{External Validity}

To assess the external validity of our results, we compare the distribution of demographic characteristics in our Facebook samples with the national census, other nationally representative samples, and the population of Facebook users in both countries. We assess the extent to which weighting allows our samples to more closely approximate national populations. We also examine responses to attitudinal and behavioral survey questions, as well as to a canonical framing experiment.

\subsection{Are Facebook samples representative?}

We compare data from four main sources: the national census, nationally representative survey samples (LAPOP and Afrobarometer), the Facebook population, and our Facebook surveys. The census serves as our benchmark for whether our samples accurately represent the national population. Comparisons with other representative survey samples allow us to evaluate the comparative advantages or disadvantages of the Facebook platform for cost-effectively collecting data with the goal of approximating a nationally representative sample. Comparing our Facebook sample with the Facebook population allows us to identify the selection of platform members into the survey. We can also compare the Facebook population to the census population in order to illuminate the limitations of the platform to recruit samples that resemble the national population. Figure 2 shows these comparisons for our unweighted and weighted Facebook samples in Mexico and Kenya, respectively.

In both countries, the unweighted Facebook samples differ most from the national population with respect to education and age. The application of weights helps to ameliorate some of these demographic imbalances. In Mexico, the weights correct the overrepresentation of respondents over 50. In Kenya, the age weights seem to perform somewhat worse and the weighting process does not result in better representation of older respondents. With respect to education, raking reduces some of the imbalance but does not completely eliminate it. Here, a comparison with the Facebook population is illuminating. Facebook reports an "unspecified" educational status for half of the population of users in Mexico and $40 \%$ of users in Kenya. While targeted oversampling of low-education respondents helped reduce imbalance in our samples, the surfeit of missing education information hindered our ability to fully correct it.

We also examine the representativeness of our samples on characteristics that are not incorporated into the weights. Results are mixed regarding the match between the Facebook samples and national populations on measures of religion, language spoken, and marital status. Importantly, weighting does not substantially affect the distribution of these variables, which are not incorporated into our weights. This suggests a negligible correlation between age, gender, education, and geography and the other variables we examine. Notably, while both samples suffer from some remaining imbalances after weighting, these demographic imbalances are often similar to or smaller in magnitude (though different in direction in some cases) to the imbalances in the high-quality samples collected by the LAPOP and Afrobarometer in-person surveys.

\subsection{Can Facebook surveys recover benchmark public opinion estimates?}

We next compare responses from our Facebook samples to opinion questions we replicated from surveys fielded around the same time as our Facebook surveys.

In Mexico, we replicated the question wording and response options for a question that LAPOP asked in its 2019 survey of Mexican respondents [20]. The question asks whether economic growth or 
environmental protection should be prioritized. The results from the LAPOP and Facebook samples are presented in Figure 3. Facebook respondents were substantially more likely to answer that environmental protection should be given the highest priority, and slightly less likely to choose responses at the economic growth end of the Likert scale. 

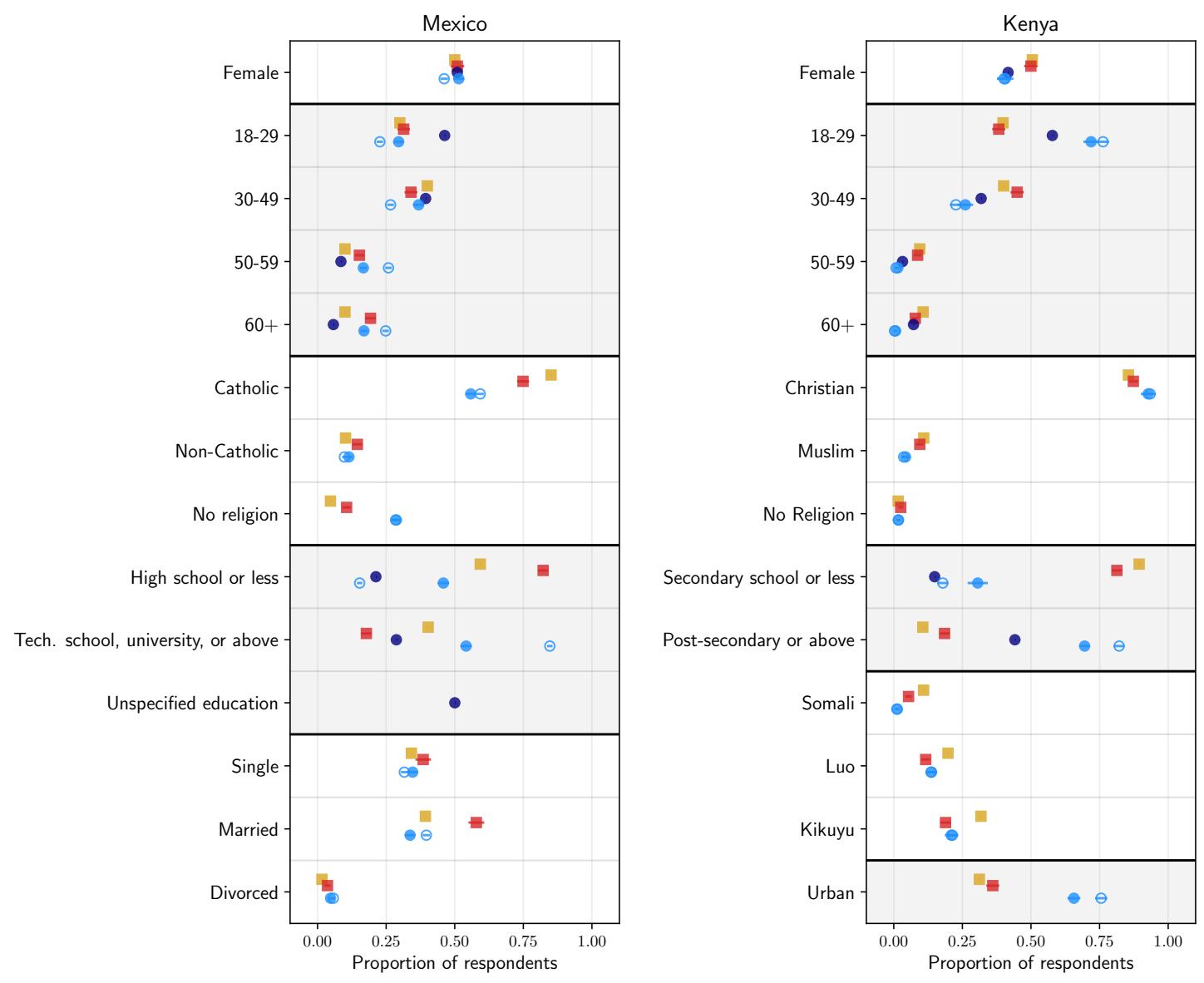

- Facebook Sample (weighted)

Figure 2: A comparison between the demographics reported in the national census, nationally representative survey samples (LAPOP/Afrobarometer), the Facebook population, and our Facebook sample for Kenya and Mexico. The Facebook sample is weighted using raking to match the national census on gender, education, region, and age. Mexican comparison data are from INEGI [15] and LAPOP. Kenyan comparison data are from the 2019 national census [18] and the 2016 Afrobarometer [1]. 


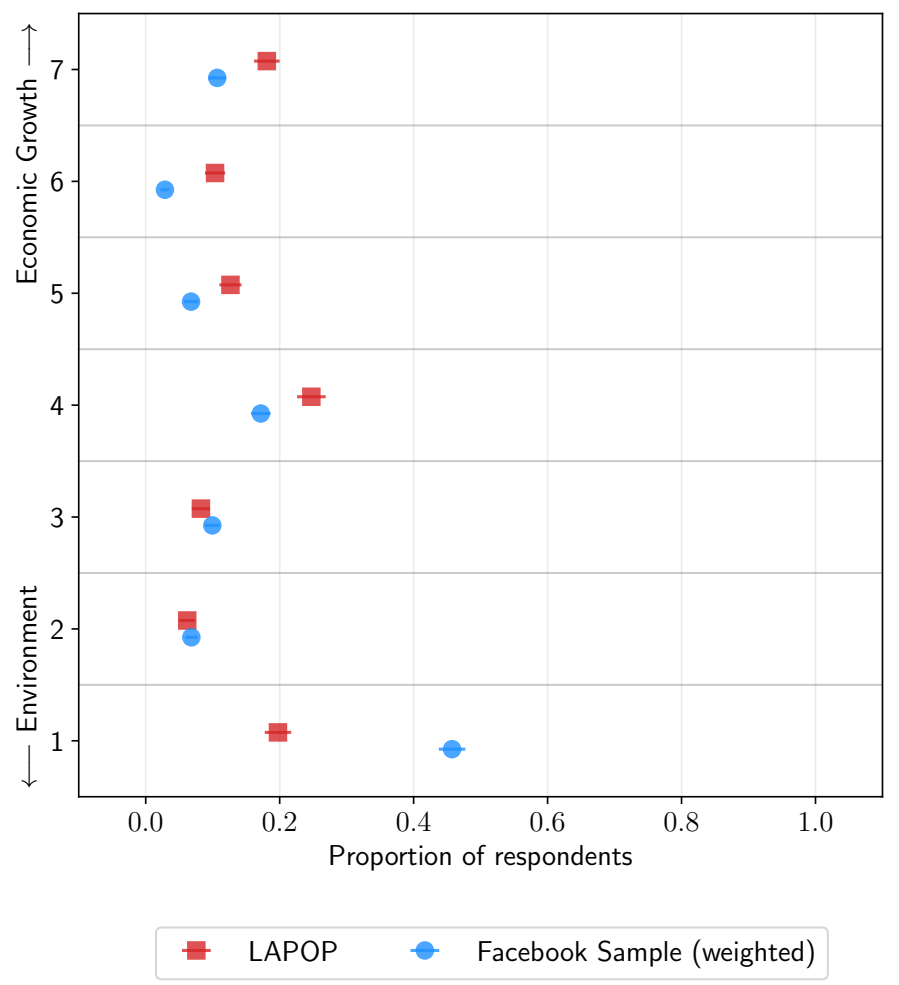

Figure 3: This figure shows responses from LAPOP and Facebook samples, to the question of whether environmental protection (1) or economic growth (7) should be given priority. Results are weighted for the Facebook sample, according to the procedure described in section 3.4, and unweighted for the LAPOP sample, consistent with the survey design documentation. 
In Kenya, we similarly replicate questions from the Afrobarometer survey. ${ }^{20}$ First, we compare perceptions of political freedom and opinions of political leaders between the Facebook and Afrobarometer samples. As the bottom two rows of Figure 4 show, similar proportions of Facebook and Afrobarometer respondents feel that they are free to say what they think, and approve of President Uhuru Kenyatta.Thus, political attitudes appear quite similar across the samples.

On the other hand, Facebook respondents are more likely to report having engaged in politics. Slightly higher numbers of Facebook respondents report having voted ${ }^{21}$ and attended a community meeeting, and even greater numbers report having taken other types of political action. Facebook survey respondents in Kenya appear to be somewhat more politically engaged than the Afrobarometer sample, but one unexpected finding is that they are less likely to feel close to a political party.

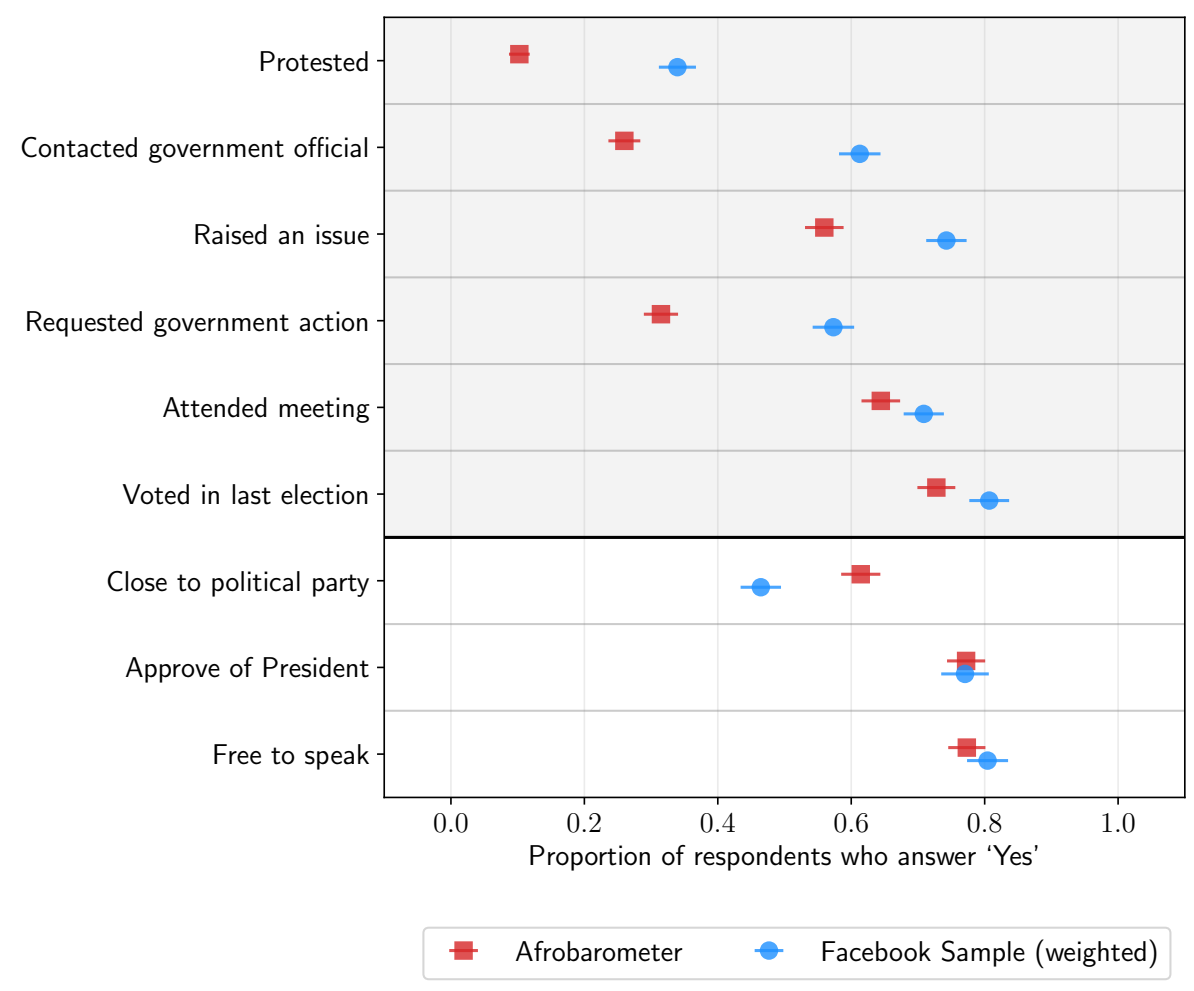

Figure 4: This figure shows responses from Afrobarometer and Facebook samples in Kenya, to questions related to political attitudes. It also compares self-reported behaviors including identifying with a political party, voting, and engaging in activities such as community meetings and protests. Estimates for both samples have been weighted using the individual weights provided in the Afrobarometer survey, and the raking procedure described above for the Facebook survey.

\subsection{Can Facebook samples recover behavioral lab experiment results?}

In Kenya, we also replicated a canonical behavioral experiment — Tversky and Kahneman's (1981) "disease problem" — which has been conducted in a wide range of contexts over time. Supplementary

\footnotetext{
${ }^{20}$ At the end of our survey we asked if respondents had been previously surveyed by any other organization. While $47 \%$ reported that they were surveyed by census enumerators, less than $1 \%$ reported being surveyed by the Afrobarometer. $16 \%$ said they were surveyed but did not recall by whom.

${ }^{21}$ Interestingly, the proportion of Facebook voters is close to the government-reported turnout rate of $79 \%$ for the August 8, 2017 general election [14].
} 
Section 4.2 describes the experiment in detail. Table 3 shows the results from our Facebook sample in Kenya, which are similar to the original sample and to other Western convenience samples [3].

Table 3: Replication of Tversky and Kahneman (1981) Disease Problem

\begin{tabular}{|l|ll|ll|lc|}
\hline & \multicolumn{2}{|c|}{$\begin{array}{c}\text { Kenya Facebook } \\
\text { Sample (unweighted) }\end{array}$} & \multicolumn{2}{|c|}{ Tversky and Kahneman } & \multicolumn{2}{c|}{$\begin{array}{c}\text { Berinsky, Huber, } \\
\text { and Lenz }\end{array}$} \\
\hline Options & Save & Die & Save & Die & Save & Die \\
\hline Certain & $62 \%$ & $36 \%$ & $72 \%$ & $22 \%$ & $74 \%$ & $38 \%$ \\
Risky & $38 \%$ & $64 \%$ & $28 \%$ & $78 \%$ & $36 \%$ & $62 \%$ \\
\hline
\end{tabular}

The table shows the proportion of respondents choosing certain and risky policies to manage a disease, when the policies are framed in terms of lives saved vs. deaths. When the policies are framed in terms of the number of lives saved, a majority of respondents prefers the certain policy. When the policies are framed in terms of the number of people who will die from the disease, a similar majority prefers the risky option.

\section{Survey costs}

Researchers typically weigh internal and external validity concerns against the relative costs of different survey tools. For Facebook surveys, these typically include the advertising costs for using the Facebook platform and optional incentive costs associated with paying respondents. We check whether surveys are cost-effective according to different definitions of cost-effectiveness.

Table 4 shows the reach and total spending of our survey advertising campaigns. The mean cost per completed survey was $\$ 0.16$ in Mexico $^{22}$ and $\$ 1.07$ in Kenya. ${ }^{23}$ This is quite inexpensive in Mexico, but even in Kenya the cost is comparable with the cost of recruiting online convenience samples using platforms such as MTurk or Lucid. ${ }^{24}$ In particular, these costs are substantially cheaper than the only feasible alternatives: online panels or in-person field surveys. In Supplementary Information Section 3, we explore variation in the cost of reaching different demographic groups. These costs vary because Facebook ads are deployed using a bidding system in which hard-to-reach populations are more expensive for advertisers to target.

\footnotetext{
${ }^{22}$ These statistics reflect the full campaign, including our low-education oversample. In Section 3 of the Supplementary Information, we include separate data for the initial sample (without education targeting) and for the oversample in which we targeted respondents with a high school degree or lower levels of education.

${ }^{23}$ This figure is derived from Facebook's count of completed surveys. This falls to $\$ 0.56$ if we consider all 2,323 surveys initiated on Qualtrics, and $\$ 0.89$ if we consider all 1,452 surveys completed on Qualtrics which were determined to be valid and were used in the analysis.

${ }^{24}$ We make this comparison only for context, since these platforms do not enable researchers to contact survey respondents in Kenya.
} 
Table 4: Reach of survey

\begin{tabular}{|l|rr|}
\hline & Mexico & Kenya \\
\hline Reach & 439,056 & 318,960 \\
Impressions & 492,564 & 649,264 \\
Clicks & 24,314 & 8,206 \\
Survey results & 5,313 & 1,211 \\
Total spent & $\$ 847.76$ & $\$ 1,293.91$ \\
\hline Click through rate (\%) & 0.049 & 0.013 \\
Completion rate $(\%)$ & 0.011 & 0.002 \\
Cost per click $(\$)$ & $\$ 0.04$ & $\$ 0.16$ \\
Cost per completed survey $(\$)$ & $\$ 0.16$ & $\$ 1.07$ \\
\hline
\end{tabular}

These survey results are those reported by Facebook (using the pixel) and therefore do not match our completions reported by Qualtrics. The click through rate and the completion rate are defined with respect to impressions.

\section{Conclusion}

Given its broad user base, Facebook enables researchers to quickly and reliably recruit subjects from countries that are underrepresented on existing online subject recruitment platforms. We have provided a framework for quality evaluation that is based on internal validity, external validity, and cost. Using our experiences running quota-sampled surveys in Mexico and Kenya, we shed light on the tradeoffs and considerations involved in using Facebook for this purpose. We show that we can successfully and cheaply recruit respondents in our countries of interest, with a broad range of demographic characteristics, geographic locations, and opinions. Facebook also presents a unique opportunity to rapidly gather real-time attitudes and sentiments in the face of current events. In our experience, hundreds of survey responses can be gathered within a few days, even when targeting specific demographic strata or geographic regions. Facebook is also cost-effective; Facebook offers a much cheaper way to reach respondents than online panels or face-to-face surveys.

On the other hand, our assessment of internal validity considerations shows some limitations of the Facebook advertising platform. We could not fill a number of cells in Kenya, and education poses a particular problem because Facebook does not maintain educational status for many users in both countries. Facebook accurately assigned the vast majority of respondents to gender groups in both countries and to age cohorts in Mexico, and Facebook-assigned geographic locations matched self-reported locations in about two-thirds of cases in both countries. But Facebook mischaracterized about half of Kenyans' ages. Encouragingly, we find that survey completion times are reasonable in both countries and that $98 \%$ of respondents in Kenya passed an "easy" attention check, suggesting that respondent inattention and haste do not compromise internal validity.

From an external validity standpoint, we find that Facebook survey samples are biased with respect to both the population of Facebook users and the national population as a whole. Raked weights ameliorated but did not completely remove these biases. One encouraging finding is that we successfully replicated the results from Tversky and Kahneman's risk-framing experiment, suggesting that Facebook may have potential as a recruitment tool to broaden the audiences used for behavioral experiments.

With respect to costs, we find that these can be quite low, but they are highly dependent on the targeting strategy used. Facebook may be most cost-effective in urban areas or among otherwise internet-connected populations; these populations can be identified ex ante through the use of Facebook's estimates of Daily and Monthly Active Users (DAU/MAU). Naturally, the use of incentives for survey completion influences the cost-quality tradeoff. In Mexico, we successfully recruited respondents without incentives, likely because the survey was quite short and internet penetration is substantially higher than in Kenya. In Kenya, because much of the population uses rate-limited mobile internet, we provided a modest airtime credit as compensation. This incentive likely encouraged greater par- 
ticipation among resource-constrained respondents, but it also led to instances of gaming and viral sharing of the survey link. While link sharing complicates our efforts to satisfy the assumptions laid out in Section 2.3, future research could investigate strategies for leveraging the social nature of the platform, for example by engaging in snowball sampling that promotes forwarding of the survey link.

In addition to the tradeoffs discussed above, scholars should consider context before deciding to use Facebook to recruit subjects. Using Facebook as a method of respondent recruitment will be particularly successful in contexts where 1) phone and internet penetration is widespread, 2) literacy rates are relatively high, and 3) recent census data are available. ${ }^{25}$ Researchers looking to adopt this method should also keep in mind that the nature of users' interactions with and expectations for Facebook might influence internal validity. While we have tested this method in two competitive democracies, in authoritarian states (where Facebook is permitted), citizens who answer surveys on the platform might have different assumptions about the government's surveillance of their responses. Researchers should consider these concerns in the survey design process, and future research could extend our analysis to other countries and contexts.

Additionally, algorithmic bias and ethics pose fundamental concerns for using the Facebook platform for research. First, there is very little understanding of how Facebook's ad targeting algorithm works and the extent to which this introduces selection on unobservables into survey samples. Future work could compare different ad targeting strategies to elucidate the influence of Facebook's optimization algorithm. Second, there is a need for a clearer ethical framework around running remote surveys, including better guidance on the types of approvals needed from national ethics review boards. Institutional review boards will likely lag behind evolving research environments. We recommend that researchers use their best judgement when designing remote surveys on social media, as they would if they were recruiting and surveying respondents face-to-face. Knowledge of the local context will continue to be invaluable in survey design. ${ }^{26}$

All survey efforts involve tradeoffs between validity and costs. In this paper, we articulate a framework for evaluating these tradeoffs and assessing them in the context of Facebook surveys in Kenya and Mexico. With the global growth in mobile internet penetration and with the social distancing requirements necessitated by the current pandemic, it seems inevitable that the use of online survey samples will continue to increase over time and the questions we have raised here will become increasingly important to consider.

\section{Acknowledgements}

The authors thank Michaël Aklin, Baobao Zhang, Blair Read, Peter Howe, Jennifer Marlon, Anthony Leiserowitz, and André Grow for helpful comments. We thank Warsama Abdifitah, Kibuchi Eliud, Ahmed Hared, Lilian Ligeyo, Laban Okune, Gustavo Ovando-Montejo, Nelson Ngige, and Eunice Williams for translation assistance.

\section{Funding}

This work was supported by the Summer Institute for Computational Social Science (SICSS), the Russell Sage Foundation, the Alfred P. Sloan Foundation, and the Yale Program on Climate Change Communication. Francesco Rampazzo conducted most of his research for this article as a PhD student at the Department of Social Statistics and Demography of the University of Southampton with a scholarship from the Economic and Social Research Council (South Coast Doctoral Training Partnership) [Project: ES/P000673/1].

\footnotetext{
${ }^{25}$ The ability to reweight Facebook responses is predicated on access to reliable census data, which is not available in all countries.

${ }^{26}$ We do not have space to discuss the ethical questions related to researchers paying Facebook to recruit respondents. As with many aspects of research, this question is largely outside the realm of IRB guidelines and is instead left to researcher discretion.
} 


\section{References}

[1] Afrobarometer. Afrobarometer, 2016. 2016. URL: http://www.afrobarometer.org.

[2] Matheus Araujo et al. "Using Facebook Ads Audiences for Global Lifestyle Disease Surveillance: Promises and Limitations". In: Proceedings of the 2017 ACM on Web Science Conference. WebSci '17. Troy, New York, USA: ACM, 2017, pp. 253-257. ISBN: 978-1-4503-4896-6. DOI: 10.1145/ 3091478.3091513.

[3] Adam J Berinsky, Gregory A Huber, and Gabriel S Lenz. "Evaluating online labor markets for experimental research: Amazon. com's Mechanical Turk". In: Political analysis 20.3 (2012), pp. 351-368.

[4] Adam J. Berinsky, Michele F. Margolis, and Michael W. Sances. "Separating the Shirkers from the Workers? Making Sure Respondents Pay Attention on Self-Administered Surveys". In: American Journal of Political Science 58.3 (2014), pp. 739-753. ISSN: 1540-5907. DOI: 10.1111/ajps . 12081.

[5] Clara Bicalho, Melina Platas, and Leah R. Rosenzweig. "If we move, it moves with us:" Physical Distancing in Africa during COVID-19. Working. May 2020. URL: https : // static1 . squarespace.com/static/5410f c5ae4b0b9bdbd0cde82/t/5f0b12f8edb3507adfee3b0f/1594561273957/ Social_distancing_africa_BPR2020.pdf.

[6] Taylor C Boas, Dino P Christenson, and David M Glick. "Recruiting large online samples in the United States and India: Facebook, Mechanical Turk, and Qualtrics". In: Political Science Research and Methods (2018), pp. 1-19.

[7] David E Broockman and Donald P Green. "Do online advertisements increase political candidates' name recognition or favorability? Evidence from randomized field experiments". In: Political Behavior 36.2 (2014), pp. 263-289.

[8] Alexander Coppock and Oliver A McClellan. "Validating the demographic, political, psychological, and experimental results obtained from a new source of online survey respondents". In: Research \& Politics 6.1 (2019), p. 2053168018822174.

[9] Facebook Inc. Facebook reports third quarter 2019 results. (Accessed on April 15, 2020). 2019. URL: https: //investor.fb.com/investor-news/press-release-details/2019/FacebookReports-Third-Quarter-2019-Results/default.aspx.

[10] André Grow et al. Addressing Public Health Emergencies via Facebook Surveys: Advantages, Challenges, and Practical Considerations. Preprint. SocArXiv, May 2020. DOI: 10.31235/osf. io/ez9pb.

[11] GSMA. The Mobile Economy 2020. Tech. rep. 2020.

[12] Shigeo Hirano et al. "Voter learning in state primary elections". In: American Journal of Political Science 59.1 (2015), pp. 91-108.

[13] Connor Huff and Dustin Tingley. "Who are these people?" Evaluating the demographic characteristics and political preferences of MTurk survey respondents". In: Research \& Politics 2.3 (2015), p. 2053168015604648.

[14] Independent Electoral and Boundaries Commission. Speech by Independent Electoral and Boundaries Commission Chairperson, Wafula Chebukati at the Announcement of Presidential Results at Bomas of Kenya on August 11th 201\%. Aug. 2017. URL: https://www.iebc.or.ke/uploads/ resources/IukcNTAE3I.pdf.

[15] INEGI. Porcentaje de la población de 15 años y más con algún grado escolar por entidad federativa según nivel de escolaridad y sexo, años censales seleccionados 2000 a 2015. Accessed: 20 August, 2019. 2015. URL: http://en.www.inegi.org.mx/app/tabulados/pxweb/inicio.html?rxid= 85f6c251-5765-4ec7-9e7d-9a2993a42594\&db=Educacion\&px=Educacion_04. 
[16] Kai Jäger. "The potential of online sampling for studying political activists around the world and across time". In: Political Analysis 25.3 (2017), pp. 329-343.

[17] Julie M Kapp, Colleen Peters, and Debra Parker Oliver. "Research recruitment using Facebook advertising: big potential, big challenges". In: Journal of Cancer Education 28.1 (2013), pp. 134137.

[18] KNBS. 2019 Population and Housing Census. Accessed: 9 June, 2020. 2010. URL: http: //www . knbs.or.ke.

[19] Michal Kosinski et al. "Facebook as a research tool for the social sciences: Opportunities, challenges, ethical considerations, and practical guidelines." In: American Psychologist 70.6 (2015), p. 543.

[20] LAPOP. Mexico. Accessed: 16 October, 2019. 2018-2019. URL: https://www.vanderbilt.edu/ lapop/mexico.php.

[21] Leib Litman, Jonathan Robinson, and Tzvi Abberbock. "TurkPrime. com: A versatile crowdsourcing data acquisition platform for the behavioral sciences". In: Behavior research methods 49.2 (2017), pp. 433-442.

[22] Thomas Lumley. survey: analysis of complex survey samples. R package version 4.0. 2020.

[23] Andrew Mercer, Arnold Lau, and Courtney Kennedy. For weighting online opt-in samples, what matters most? 2018. URL: https : / / www . pewresearch . org/methods / 2018/01/26/forweighting-online-opt-in-samples-what-matters-most/.

[24] Joao Palotti et al. "Monitoring of the Venezuelan Exodus through Facebook's Advertising Platform". In: PLOS One 15.2 (2020), e0229175.

[25] Steffen Pötzschke and Michael Braun. "Migrant Sampling Using Facebook Advertisements: A Case Study of Polish Migrants in Four European Countries". en. In: Social Science Computer Review 35.5 (Oct. 2017). 00011, pp. 633-653. ISSN: 0894-4393. DOI: 10.1177/0894439316666262. (Visited on $07 / 08 / 2019$ ).

[26] Danielle E Ramo et al. "Facebook recruitment of young adult smokers for a cessation trial: methods, metrics, and lessons learned". In: Internet Interventions 1.2 (2014), pp. 58-64.

[27] Leah R. Rosenzweig and Yang-Yang Zhou. "Team and Nation: Sports, Nationalism, and Attitudes toward Refugees in Kenya and Tanzania". Accessed: 9 May, 2020. 2019. URL: https:// static1. squarespace.com/static/5410f c5ae4b0b9bdbd0cde82/t/5d2e25f26c8ebb00017ed0b3/ 1563305467356/20190613AB_PAP_update_20190627.pdf.

[28] Valentina Rotondi et al. "Leveraging mobile phones to attain sustainable development". In: Proceedings of the National Academy of Sciences (2020).

[29] Timothy J Ryan. "What makes us click? Demonstrating incentives for angry discourse with digital-age field experiments". In: The Journal of Politics 74.4 (2012), pp. 1138-1152.

[30] David Samuels and Cesar Zucco Jr. "The power of partisanship in Brazil: Evidence from survey experiments". In: American Journal of Political Science 58.1 (2014), pp. 212-225.

[31] Lie Philip Santoso, Robert Stein, and Randy Stevenson. "Survey experiments with Google consumer surveys: Promise and pitfalls for academic research in social science". In: Political Analysis 24.3 (2016), pp. 356-373.

[32] Hana Ševčíková. Explorer of World Population Prospects. 2020.

[33] United Nations. World Population Prospects Volume 1, Volume 1, 2019. ISBN: 978-92-1-148327-7.

[34] U.S. Securities and Exchange Commission. Facebook Inc 2019 Annual Report 10-K. 2019. URL: https://sec.report/Document/0001326801-20-000013/fb-12312019x10k.htm.

[35] World Bank. World Bank Open Data. 2020. URL: https ://data.worldbank.org/indicator (visited on 05/20/2020). 
[36] Baobao Zhang et al. "Quota sampling using Facebook advertisements". In: Political Science Research and Methods (2018), pp. 1-7. 


\title{
Survey sampling in the Global South using Facebook advertisements: Online Appendix
}

\author{
Leah R. Rosenzweig*r), Parrish Bergquist $†$ Katherine Hoffmann Pham; \\ Francesco Rampazzo, \& Matto Mildenberger $₫$
}

October 15,2020

\section{Contents}

1 Extended discussion of internal and external validity 3

1.1 Detailed discussion of Internal Validity Results . . . . . . . . . . . . . . . 5

2 Recruitment and sampling $\quad 6$

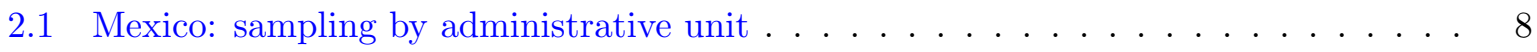

2.2 Kenya: sampling by geolocation . . . . . . . . . . . . . . . . . 10

2.2 .1 Attention Checks in Kenyan Survey . . . . . . . . . . . . . . . . . . 12

3 Survey Costs $\quad 12$

3.1 Variation in costs by strata . . . . . . . . . . . . . . . . . . . . . 13

3.2 Costs by round of data collection . . . . . . . . . . . . . . . . . . 13

3.3 Variation in costs for specific populations of interest . . . . . . . . . . . . . 14

4 Survey Instruments $\quad 16$

4.1 Mexico Survey Instrument . . . . . . . . . . . . . . . . . . . . . 16

4.2 Kenya Survey Instrument . . . . . . . . . . . . . . . . . . . . . . . 23

* Postdoctoral Fellow, Graduate School of Business, Stanford University, lrosenzw@stanford.edu.

(r) Order of the authors was randomized.

${ }^{\dagger}$ Assistant Professor, McCourt School of Public Policy, Georgetown University, pb968@georgetown.edu.

${ }^{\ddagger}$ PhD Candidate, Stern School of Business, New York University, khof@nyu.edu.

${ }^{\S}$ Career Development Fellow in Marketing and Consumer Demography, Saïd Business School and leverhulme Centre for Demographic Science, University of Oxford, francesco.rampazzo@sbs.ox.ac.uk.

ॠAssistant Professor, Department of Political Science, University of California Santa Barbara, mildenberger@ ucsb.edu. 


\section{Extended discussion of internal and external validity}

In this section, we continue the discussion of internal and external validity. As in the paper, we use internal validity to refer to the survey's success in accurately measuring the specific population targeted by the advertising strata. External validity refers to the survey's success in generalizing to a broader population. We have primarily framed positivity, ignorability, and independence as violations of external validity. However, as shown in Table1, we may draw analogies to these concepts in the context of internal validity as well. Below, we discuss a few internal and external validity considerations in more depth.

\begin{tabular}{|c|c|c|}
\hline & Internal Validity & External Validity \\
\hline Positivity & $\begin{array}{l}\text { Some members of the Facebook population } \\
\text { have no chance to enter our sample }\end{array}$ & $\begin{array}{l}\text { Some parts of the population of interest are } \\
\text { not on Facebook }\end{array}$ \\
\hline Igno & $\begin{array}{l}\text { Respondents are not a representative sample } \\
\text { of the Facebook population }\end{array}$ & $\begin{array}{l}\text { Survey respondents are not a representative } \\
\text { sample from the broader population }\end{array}$ \\
\hline Inde & $\begin{array}{l}\text { Responses are correlated across and between } \\
\text { survey strata }\end{array}$ & $\begin{array}{l}\text { The Facebook population is a subnetr } \\
\text { the broader population }\end{array}$ \\
\hline
\end{tabular}

Figure 1: Ways in which positivity, ignorability, and independence may be violated, framed from the perspective of internal and external validity

Who is on Facebook? A first-order question regarding the use of Facebook is who has access to the platform. In many countries, Facebook penetration may be limited because Facebook use requires access to the internet, either through a mobile phone or a computer. However, it is worth noting that in some settings, Facebook has made efforts to expand such access by zero-rating its services in combination with partner telecoms through its Free Basics program. ${ }^{1}$ Using Facebook also requires a minimum level of technological literacy in order to navigate the digital interface, as well as the ability to read in one of Facebook's supported languages in order to navigate the menu options. Finally, even users who overcome these two barriers may choose not to open a Facebook account. Together, these factors can limit the external validity of Facebook studies because some parts of the population may not be available in the sample frame.

Who sees and responds to surveys? As Facebook users interact with ads, Facebook attempts to model this behavior and target future ads towards individuals that are most likely to complete the advertised task. While this is helpful for companies advertising their products, it might be problematic for survey research. First, algorithmic targeting may mean that some groups of Facebook users may never see the survey ads, because Facebook determines that the ad placement is not a good use of resources (this can be considered a violation of the positivity assumption from the perspective of internal validity). Second, Facebook's optimization algorithm, if unrestrained, might yield a biased sample of individuals who are similar on some observable or unobservable characteristics that are associated with propensity to take the survey (a violation of the ignorability assumption from an internal validity perspective).

Who can be targeted? The Facebook API allows advertisers to target users according to location, gender, language, and age, but also more ambiguously-defined concepts such as education status, life events, interests, and behaviors. As an example of the richness of these categories, there are targeting codes for people who are commuters or frequent travelers, medical professionals,

\footnotetext{
${ }^{1}$ In Kenya, we identified 25 people who reached our Qualtrics survey through this channel, although only 7 of those responses were retained as valid.
} 
active military, newlyweds, interested in different types of loan products, interested in the Gujarati language, and interested in Da Nang International Airport.

Nevertheless, the relevance of some commonly-used categories depends on the context. As we found in the case of educational and geographic classifications, the targeting categories available through Facebook might not always match the most natural categories in the host country. Other concepts, such as conservative/liberal/moderate political orientation, are specific to the US context. Furthermore, we found that some categories that we would have liked to target - such as speakers of particular regional languages - are not available in the system. More generally, it is not entirely clear how each of these categories is defined and assigned to individual user profiles.

Together with the challenges documented in the main paper - i.e., the fact that some targeting combinations are not available due to legal restrictions, and the fact that it is unclear how accurate the targeting approach is - these factors act as limitations on internal validity of the Facebook sample.

What are the implications of advertising on a social networking site? As noted in the main paper, one of the challenges with running surveys on a social networking site is the chance that responses may be drawn according to this network structure. A second problem is viral cheating. Since the network is unobserved to us as researchers, it can be difficult to assess the extent to which either of these is a problem. However, we examine a few possible indicators of these behaviors.

The first concern is networked sharing. As noted in the main paper, Facebook recorded 1,211 completed surveys in Kenya, whereas Qualtrics recorded 1,452 valid surveys. By this measure, approximately $20 \%$ of responses may have come from sources other than our Facebook ads, such as link sharing among friends.

The second concern is duplicate survey takers. Our final count of 1,452 Kenyan respondents excludes duplicates where multiple people provided the same phone number with no valid reason (we identified 24 such duplicates with no reason for the duplicate provided, and 8 survey takers who provided a reason why they were sharing a phone, e.g. "a friend who is a neighbor"). Interestingly, no phone number was provided more than twice, suggesting that if people were gaming the survey to accrue the incentives, they were sophisticated enough to supply different phone numbers.

Finally, we note that 1,206 of our 1,452 valid surveys had unique IP addresses; the remaining respondents shared an IP address with 7 - 98 other people. This metric can not distinguish between cheating, link sharing, or coincidence, since duplicate IP addresses may result from respondents using the same internet connection to answer the survey independently (e.g. in a home, office, airport, or coffee shop). However, we note that mass cheating seems costly because someone falsifying 98 responses would need to create 98 different phone numbers and run through the complete survey 98 times in order to gain the equivalent of US $\$ 49$.

What is the alternative to online surveys? In practice, internal and external validity concerns are always present to some degree, and survey research therefore typically involves a tradeoff between quality and cost. For instance, achieving a larger and representative sample of a population of interest usually comes at the price of added time and money. In evaluating the quality-cost trade-off, researchers are sensitive to both direct costs of recruiting and compensating respondents, as well as the broader time and resource costs associated with high quality sample collection.

In the Global South, these latter costs can be substantial. For in-person surveys, the World Bank reports that "70 to 90 percent of the total survey cost goes to field implementation" (Iarossi 2006, 
p. 18). Paying salaries and per diems for enumerators and transportation allowances for research teams make up the largest part of these costs. Large-scale surveys, especially those that seek to be nationally representative, can cost tens of thousands of dollars. For instance, a recent rapid baseline survey conducted in Sierra Leone, which has a population of about 8 million, with 2400 respondents cost around $\$ 70,000$. This survey was limited to a 20 -minute interview and was conducted by a local research firm. Even phone-based surveys in developing countries can be expensive, especially when survey firms are hired to manage these. A recent quote for a phone-based survey of around 3,000 respondents in Nigeria was given at $\$ 57,000$.

Traveling to remote areas to reach respondents is costly not only in terms of finances, but also in terms of time and risks. During rainy seasons and in areas with unreliable or challenging transportation methods, enumeration can be lengthy. ${ }^{2}$ In-person enumeration also requires official approval at various administrative levels and enumerators spend time explaining the purpose of the study to local elites. Vehicle accidents are unfortunately a common occurrence and enumerators sometimes even risk their lives by taking motorbikes to reach respondents.

Fieldwork and in-person surveys offer numerous benefits, and it is not the aim of this article to suggest that online surveys should substitute for on-the-ground data collection. There are obvious advantages to in-person surveys over online studies. For instance, enumerators can code measures based on their own observations without needing to ask, such as the material the respondent's house is made out of, the respondent's attitude or demeanor during the conversation, and whether other people were present during the interview. On the other hand, several concerns with in-person research are alleviated in online research - there is no risk of enumerators coercing respondents, forging informed consent, or manipulating data. There is also no risk to enumeration teams in hostile or skeptical local communities. The choice between survey modes should therefore involve study-specific decisions about which internal validity concerns, external validity concerns, cost factors and safety concerns take precedence.

\subsection{Detailed discussion of Internal Validity Results}

We discuss the issues of greatest concern raised by our internal validity checks in the main text. Specifically, we discuss the challenges associated with targeting by age in Kenya and education in both countries. Here, we further elucidate the match between Facebook-reported and self-reported characteristics for each characteristic we examine.

In the Mexico sample, $87 \%$ of respondents reported ages consistent with their Facebook advertisement strata. ${ }^{3}$ There were no systematic patterns in which age categories were prone to mismatches. As reported in the main text, when we targeted ads to Kenyans 32 years and older, on the other hand, only $47 \%$ of respondents who reached our survey from these ads were indeed 32 years old or older. The ages of these respondents ranged from 19 to 48 years old, with a mean of 31 years.

Facebook's gender data were more accurate in both countries. In Mexico, Facebook assigned a gender that matched respondents' self-reported gender for $99 \%$ of the respondents. In Kenya, Facebook ads performed almost as well, with $90 \%$ of respondents reporting a gender identity in the

\footnotetext{
${ }^{2}$ For instance, enumeration for the nationally representative Afrobarometer surveys is usually conducted over a period of three weeks and involves a large team of enumerators and field research managers.

${ }^{3}$ We asked age through an open-ended question. Some respondents $(n=52)$ did not provide their age, and these individuals are not included in this calculation.
} 
survey that matched the ad that targeted them. The $10 \%$ of respondents who were recruited from an ad that was targeted toward the opposite gender might have resulted from respondents sharing ads with friends so that they could also benefit from taking the survey and receiving 50 KES in airtime. It would not be surprising that greater sharing would have occurred in the context of the incentivized survey in Kenya, compared to the non-incentivized survey in Mexico.

Geographic targeting was slightly less accurate in both countries. In Mexico, $67 \%$ of respondents reported living in a municipality that matched their Facebook advertising target cell. Most of these errors were a function of mismatches within (rather than between) the four main regions of Mexico: $92 \%$ of respondents had matching self-reported and Facebook-advertised regions. Most Kenyan respondents were targeted geographically via clusters of Afrobarometer coordinates, which could fall across multiple provinces. Therefore, we first checked whether the province corresponding to the respondent's self-reported location matched the province of at least one of the corresponding Afrobarometer coordinates. Using this definition, we achieved a $64 \%$ match rate between the Facebook target province and the Afrobarometer province. The remainder of respondents in hardto-reach age or education groups $(\mathrm{n}=67)$ were targeted at the province level. In these strata, $69 \%$ of respondent-reported towns of residence fell within the targeted province.

\section{Recruitment and sampling}

To recruit respondents for our surveys, we first created Facebook pages representing our survey campaigns, and placed ads from these pages to target people living in Mexico and Kenya. An example of these ads is shown in Figure 2. After clicking on the Facebook ad, respondents were sent to a survey hosted on Qualtrics. For Kenyan respondents, the first survey question asked respondents to choose from one of five possible languages (English, Kiswahili, Kikuyu, Luo, and Somali) in which to take the survey. For Mexican respondents the survey was administered in Spanish. Upon completing the survey, respondents were directed to a thank you page with an embedded Facebook "Pixel" which allowed Facebook to track which of the users that clicked on the ad actually completed the survey.

To help advertisers maximize their budgets, Facebook attempts to optimize ad placement according to a specific campaign objective specified by the advertiser. In our case, we used "conversion" targeting to optimize for survey completions as measured by these pixels. The Facebook targeting algorithms may introduce selection bias. To address this bias, we needed to develop a strategy to broaden the diversity and representativeness of the sample.

We use quota sampling approaches modeled on well-respected, in-person representative samples drawn from our case countries. Facebook allows advertisers to define "custom audiences" in order to target ads based on a number of personal characteristics. There are some constraints on how scholars can target their surveys since Facebook does not encode and make available all possible strata. Additionally, depending on the nature of the ad, it may be considered discriminatory to target groups based on observable characteristics such as race or gender. For example, ads involving housing, employment, or credit are subject to a limited set of targeting options. ${ }^{4}$ Despite these constraints, we were able to design target cells based on gender and age, which are the demographic characteristics used in benchmark nationally representative surveys in these countries. We also targeted respondents by geography, again in a manner that was modeled on the geographic

\footnotetext{
${ }^{4}$ For details, see: https://developers.facebook.com/docs/marketing-api/audiences/special-ad-category
} 


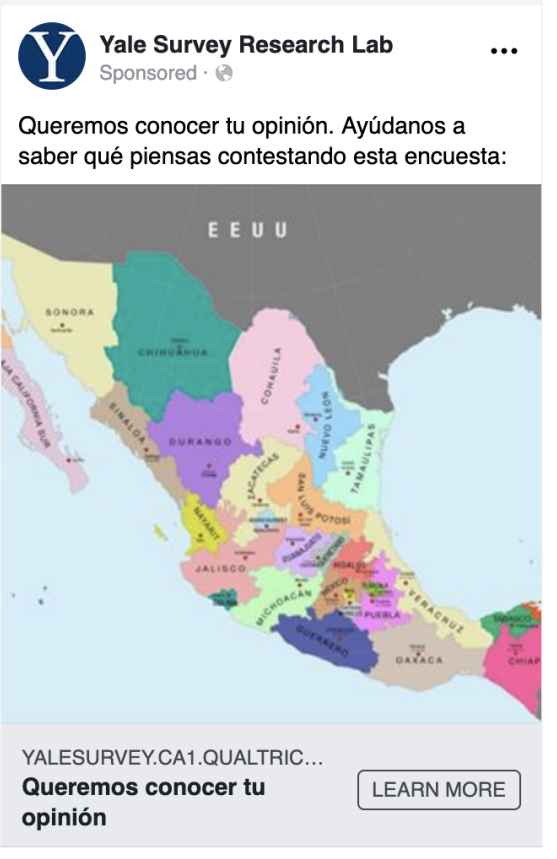

(a) Mexico

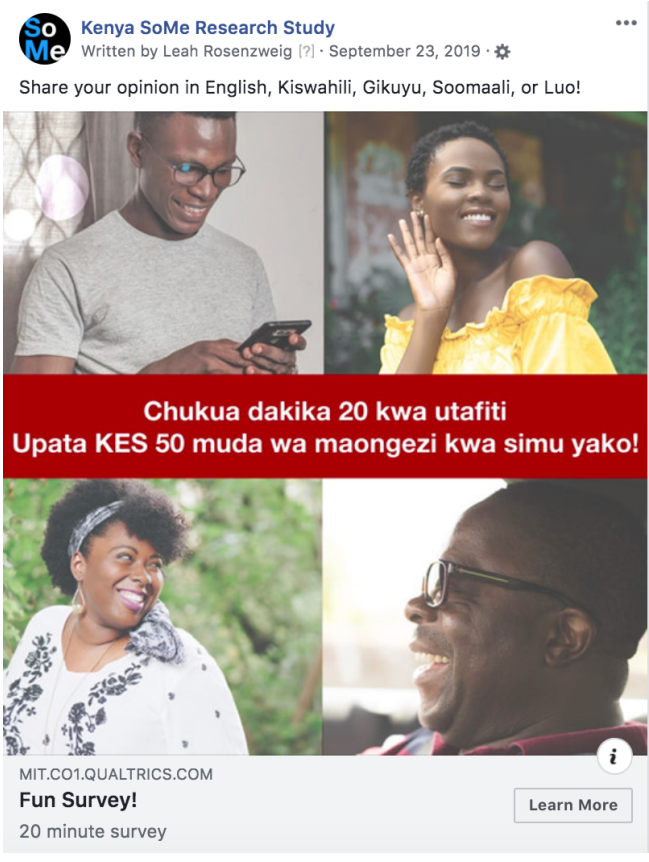

(b) Kenya

Figure 2: Example Facebook advertisement inviting respondents in one of our quota cells to participate in our public opinion survey.

stratification used by in-person surveys.

Facebook allows for two different types of geographic targeting strategies. First, researchers can directly target audiences by providing a latitude and longitude of interest, as well as a radius defining the catchment area. Second, researchers can use Facebook's predefined geographic entities, which it classifies as large/medium/small "geo-areas", metro areas, cities/subcities, and neighborhoods/subneighborhoods. These entities generally correspond to known administrative units, but the correspondence is not perfect. For example, in Mexico, municipalities were alternately classified as subcities or medium geo-areas. In Kenya, targeting was available for each of the country's eight provinces, but not for all 47 counties, which have been the predominant unit of administrative organization since devolution in 2010. The availability of county targeting does not seem to be an issue of granularity, since it is possible to target specific areas of Nairobi such as Mathare (an informal settlement) or Kilimani Estate (an upscale neighborhood).

In Mexico, we target respondents according to Facebook's defined geographic entities. In Kenya, we target primarily based on latitude and longitude, although we supplement this sample with respondents from hard-to-reach groups recruited at the province level. We are therefore able to examine the viability of both these approaches to geographic targeting.

Without using quota-based ad cells, we expect that our sample would be composed of individuals who are very similar to each other. Since we target strategically, our sample includes respondents from throughout the age, gender, and geographic distributions of our case countries' residents. Below, we describe our sampling approaches in more detail. 


\subsection{Mexico: sampling by administrative unit}

To draw a nationally representative sample of Mexican residents, we targeted Facebook users by age, gender, and geographic location. Our geographic sampling protocol mirrors the procedure used by Latin American Public Opinion Project (2017) (LAPOP) to sample within small, medium, and large municipalities. ${ }^{5}$ However, rather than using arbitrary population size cutoffs to categorize Mexico's 2,456 municipalities ${ }^{6}$, we group municipalities according to the distribution of Mexican residents across them. Specifically, using census data we calculated that one quarter of Mexicans reside in municipalities with fewer than 53,442 residents; one quarter in municipalities with 53,443220,292 residents; one quarter in municipalities with 220,293-661,176 residents; and one quarter in municipalities with more than 661,177 residents. Therefore, we assign each municipality to one of these four categories. Within each of the four major regions of the country, we target these quartiles with equal weights, to gather approximately equal numbers of residents from each quartile in each region. To ensure a representative sample within the cells defined by region and size of municipality, we further stratified based on gender (male, female) and age (18-29; 30-49; 50-59; $60+)$ categories. These age categories are based on the age groups reported by the Mexican census bureau's municipal-level population summaries (INEGI 2015).

In total, this sampling procedure created 128 cells $(4$ regions $\times 4$ municipality size groups $\times 2$ genders $\times 4$ age groups). ${ }^{7}$ We collected a minimum of 25 responses from each cell, turning our ads off at regular intervals for cells that had been filled. We first collected 1,113 responses on 17 August 2019 by turning on ads for quotas located in Central Mexico. We then advertised to cells in the rest of the country on 18 August 2019, collecting 3,239 responses. After dropping individuals with self-reported ages under $18(\mathrm{n}=165)$ and one individual without a recorded stratum ${ }^{8}$, we were left with a final sample size of 4,396. Respondents were not compensated for their participation in the survey, and we did not collect any identifiable data from any individual respondent.

After this initial data collection, we found that our sample underrepresented Mexicans whose highest level of completed education was high school or below. We thus conducted a second round of data collection, which layered education targeting onto the previously constructed strata. We targeted respondents in each of our previously constructed geographic-demographic strata who had less than a high school education. After collecting this low-education sample and dropping individuals who did not report their age, gender, geographic location, or education level, our sample contained 5,202 individuals.

We then used iterative proportional fitting (raking) to create weights for all respondents according to the distribution of the Mexican population across gender, education, and age groups and within regions. To avoid extreme values in the weight vector, we used the marginal distribution of

${ }^{5}$ LAPOP collects a sample that is stratified by four geographical regions, the size of municipality $(100,000+$ inhabitants; 25,000-100,000 inhabitants, and less than 25,000 inhabitants), and urban and rural areas within municipalities.

${ }^{6}$ These municipalities include the 16 municipal jurisdictions within Mexico City, which is designated as a unique state-level jurisdiction and divided into distinct municipalities.

${ }^{7}$ One limitation of the Facebook advertising platform is that custom audiences cannot target more than 250 unique geographic locations, which means that a single ad could not be used to target a quartile with more than 250 municipalities. Because a number of our low-population cells contained more than 250 Mexican municipalities, we split low-population, high-municipality cells into multiple "sub-cells".We thus ran Facebook advertisements on 184 unique strata. However, we pool these "sub-cells" in our analysis so that all respondents are assigned to one of the 128 core quota cells.

${ }^{8}$ This likely occurred because the user inadvertently modified the Facebook Ad url which contained quota-related embedded data. 
gender, age, education, and region within the population, and trimmed values so that no weights extended beyond the 5th (0.10) and 95th (4.6) quantile. We created the weights using the rake function in the survey package in R (Lumley 2020).

Table 1: Classification scheme of Mexican states into regions for the purpose of quota sampling

\begin{tabular}{ll} 
State & Region \\
\hline Ciudad de México & Centro \\
Hidalgo & Centro \\
México & Centro \\
Morelos & Centro \\
Puebla & Centro \\
Querétaro de Arteaga & Centro \\
Tlaxcala & Centro \\
\hline Aguascalientes & Centro Occidente \\
Colima & Centro Occidente \\
Guanajuato & Centro Occidente \\
Jalisco & Centro Occidente \\
Michoacán de Ocampo & Centro Occidente \\
Nayarit & Centro Occidente \\
\hline Baja California & Norte \\
Baja California Sur & Norte \\
Chihuahua & Norte \\
Coahuila de Zaragoza & Norte \\
Durango & Norte \\
Nuevo León & Norte \\
San Luis Potosí & Norte \\
Sinaloa & Norte \\
Sonora & Norte \\
Tamaulipas & Norte \\
Zacatecas & Norte \\
\hline Campeche & Sur \\
Chiapas & Sur \\
Guerrero & Sur \\
Oaxaca & Sur \\
Quintana Roo & Sur \\
Veracruz de Ignacio de la Llave & Sur \\
Tabasco & Sur \\
Yucatán & Sur \\
\hline & \\
\hline & \\
\hline
\end{tabular}




\subsection{Kenya: sampling by geolocation}

In Kenya, we used a geographic quota-based approach to mimic the Afrobarometer sampling strategy. We first obtained a list of the 227 site locations from the 2016 Afrobarometer. We queried Facebook to obtain the number of users within $20 \mathrm{~km}$ of these clusters, and dropped any site that was associated with no daily users or less than 1,000 monthly active users, for one or both genders $(n=63)$. Because many of the remaining sites were close to each other in population-dense areas of the country, and because we were concerned that it would be hard to include 164 different locations in the sampling plan, we clustered these sites into 25 different groups and calculated the centroid of each group. Then, we targeted audiences within 12 miles $(\sim 20 \mathrm{~km})$ of these centroids. Within these clusters, we stratified respondents by gender. More details on the approach can be found in Figures 3 and 4 .

Anticipating that we would have a hard time reaching less educated and older respondents, we also created two ads in each of the eight provinces of Kenya to target users 32 years and older, and users with an "unspecified" education level. For these 16 ads targeting the province level, we excluded each province's capital in an attempt to reach more rural respondents. We set a quota target of five respondents for each of these 16 ads.

Figure 3: K-means algorithm for obtaining Afrobarometer cluster targets

1. Import the list of 227 AfroBarometer survey coordinates.

2. Query the Facebook marketing API to get audience estimates of the number of people within 20 kilometers of each coordinate. Drop coordinates with less than 1,000 male and/or female monthly active users, and coordinates with no male and/or female daily active users $(n=63)$.

3. Apply k-means clustering to the remaining 164 coordinates, with a pre-specified number of 25 clusters. Since the results of k-means depend on the random initialization, we experimented with random seeds until we achieved an allocation for which none of the 20-km radii around the chosen centroids overlapped. This ensured that each centroid could be used to target a distinct audience (using a radius of 12 miles).

4. Determine the total count of 2016 respondents associated with each of the 25 centroids. This count of respondents was used to determine the total weight of the centroid coordinates, which in turn dictated the number of respondents we looked for in the stratum. 


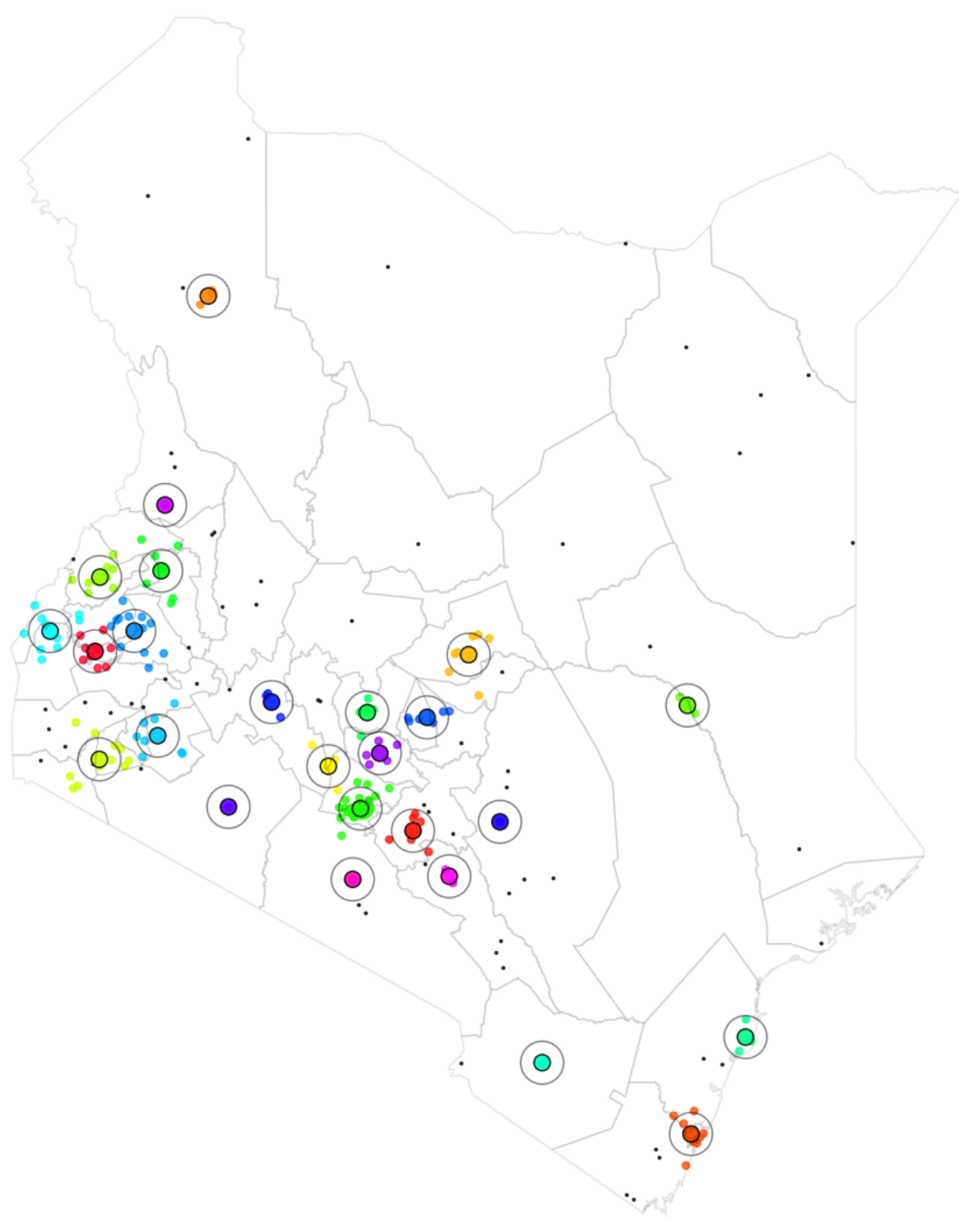

Figure 4: This map shows how Afrobarometer clusters were grouped together using the K-means algorithm. The colored dots with black outlines represent the 25 final K-means centroids used to target Facebook ads in the full study. The black circles represent 20km radii about these centroids. The colored dots with no outline represent the Afrobarometer survey clusters corresponding to each K-means centroid. The small black dots represent Afrobarometer clusters that were dropped because they had too few Facebook users. 


\subsubsection{Attention Checks in Kenyan Survey}

Following previous work on identifying "shirkers," in Kenya we included two questions in the survey to check whether respondents were paying attention and answering honestly (Berinsky, Margolis, and Sances 2014; Berinsky, Margolis, Sances, and Warshaw 2019). First, more than 20 questions after respondents were originally asked their age, we again said, "To confirm you are paying attention to the survey questions, please tell us again what is your age?" If respondents were clicking through and entering nonsense responses, we would not expect them to recall the false age they quickly entered the first time. $98 \%$ of respondents who answered both questions entered the same age in both fields and $2 \%$ entered different ages. In addition, $7 \%$ of respondents failed to answer both of these questions. Specifically, $4 \%$ did not report their age when asked the first time and $3 \%$ did not answer the second age question, which could be because they did not want to be caught falsifying responses or clicking through without paying attention.

We also included a second, more sophisticated attention check question. This question initially read like a real question, but then asked respondents to follow a set of arbitrary instructions instead of actually answering the question. The question read:

We are interested in how people conceive of democracy. We also want to know if people pay attention to survey questions. To show you are paying attention, please answer the question below and put the letter ' $k$ ' in the blank space next to the 'other' response. That's right, please select your real answers and put ' $k$ ' in the 'other' response. What if anything does democracy mean to you? (please check all that apply)

Interestingly, only $54 \%$ of respondents passed this attention check, suggesting that this might have been a particularly hard attention check. Some respondents, especially those with low levels of education, may have found it confusing or illogical; indeed, there is a statistically distinguishable difference in level of education achieved between those who passed this attention check question and those who did not. Based on these findings, we suggest that researchers include multiple attention checks of varying difficulty (Berinsky, Margolis, Sances, and Warshaw 2019), to ensure that the questions are testing attention and honesty rather than respondent comprehension or sophistication.

\section{Survey Costs}

A key question for researchers is whether Facebook surveys are cost-effective along different dimensions of cost-effectiveness. When implementing Facebook surveys, there are two types of marginal costs: (1) advertising costs and (2) costs associated with paying respondents (as we did in Kenya). Here, we focus on advertising costs. We quantify advertising costs in terms of cost per click and cost per completed survey. We focus on variations in cost by survey respondent type, since Facebook ads are deployed using a bidding system in which hard-to-reach populations are more expensive for advertisers to target. 
Table 2: Cost of Facebook targeting

\begin{tabular}{|l|lll|lll|}
\hline & \multicolumn{3}{|c|}{ Mexico } & \multicolumn{3}{c|}{ Kenya } \\
\cline { 2 - 7 } & Median & Max & Min & Median & Max & Min \\
\hline Click through rate (\%) & 5.56 & 13.25 & 2.16 & 1.2 & 6.0 & 0.7 \\
\hline Completion rate (\%) & 1.24 & 4.29 & 0.29 & 0.2 & 2.8 & 0.0 \\
\hline Cost per click $(\$)$ & 0.03 & 0.066 & 0.02 & 0.15 & 0.47 & 0.02 \\
\hline Cost per completed survey $(\$)$ & 0.13 & 0.55 & 0.07 & 1.15 & 22.07 & 0.05 \\
\hline
\end{tabular}

Note: The click through rate and the completion rate are defined with respect to the number of impressions. The mean, maximum, and minimum are computed over quota targeting cells.

\subsection{Variation in costs by strata}

One artefact of Facebook's bidding-based advertising system is that some strata are substantially more costly. This may result from the fact that many advertisers are competing for these respondents (driving up the price in the market), or that there are fewer respondents of the target type available. Other factors driving costs could plausibly include the timing of the ads (for example, ads might be more costly to place near the holiday shopping season or political elections), and the attractiveness of the ads themselves (for example, interesting ads might generate a higher click through rate). Short of actually placing survey ads, it is hard to obtain information on targeting costs, so in Table 4, we provide evidence of this variation from our own data collection.

We find that click through rates can vary dramatically across strata, from 2-13\% in Mexico and $0.7-6 \%$ in Kenya. Similarly, there is a large spread in survey completion rates. These differential response rates are translated into different costs per click and ultimately, to dramatically different costs per completed survey. In Mexico, we paid $\$ 0.07$ - 0.55 per survey, but in Kenya the spread was much larger, from $\$ 0.05-22.07$ (despite the fact that we periodically switched off high-cost strata).

Generally, we found that targeting in Mexico was cheaper and more successful than in Kenya. This likely resulted from two constraints: (1) the lower levels of Facebook usage in Kenya, and (2) the fact that our Facebook targeting criteria in Kenya were more specific with respect to geography, thereby making it more difficult to fill survey strata. Although we incentivized respondents in Kenya (and the cost for this is not included in the tables presented here), any potential increase in response rates due to the use of this incentive does not appear to have been sufficient to compensate for country-level differences.

\subsection{Costs by round of data collection}

In Mexico, we completed two rounds of data collection. The first round did not target respondents by education, but we found that the sample was skewed towards higher-education respondents. Thus, we conducted a second round of data collection in which we layered education on top of the geography $\times$ gender $\times$ age cells that we targeted in our initial data collection. For each of our initial sampling cells, we collected responses from individuals whom Facebook identified as having no more than a high school degree. Table 4 of the main text presents the reach and cost of data collection based on the full sample - i.e., including this second round of data collection targeting low-education respondents. In total, our survey reached 439,056 respondents, and we obtained 24,314 link clicks and 5,313 survey takers. Overall, the total cost per complete was $\$ 0.16$. In Ta- 
bles 3 and 4, we present the same statistics separately for the initial sample and the low-education oversample. The table shows the higher cost of surveying hard-to-reach respondents such as those with a high school or lower level of education.

In Kenya, we completed all data collection simultaneously, but included supplementary clusters to oversample older people and people with unspecified education levels. Our initial k-means targeting strategy was geographically restrictive (aiming for circles with a $20 \mathrm{~km}$ radius), whereas our oversampling strategy targeted at the province level. In other words, our oversample included harder-to-reach respondents, but we allowed Facebook to search for these respondents over a more permissive area. As a result, strata in our initial sample actually saw higher median and maximum costs to recruit, although the cheapest respondents in our initial sample (presumably in dense areas that were easy to target) were cheaper than the cheapest respondents in our oversample.

\begin{tabular}{|l|r|r|r|r|}
\hline & \multicolumn{2}{|c|}{ Mexico } & \multicolumn{2}{c|}{ Kenya } \\
\hline & Initial & Oversample & Initial & Oversample \\
\hline Reach & 251,742 & 187,314 & 282,190 & 36,770 \\
Impressions & 273,649 & 218,915 & 599,388 & 49,876 \\
Clicks & 16,265 & 8,049 & 7583 & 623 \\
Survey results & 4,380 & 933 & 1,145 & 66 \\
Total spent & $\$ 354.03$ & $\$ 493.73$ & $\$ 1,216$ & $\$ 77.91$ \\
\hline
\end{tabular}

Table 3: Reach of surveys in Mexico and Kenya, split into main sample and low-education (in Mexico and Kenya) / high age (in Kenya) oversamples

\begin{tabular}{|l|lll|llll|llll|l}
\hline & \multicolumn{3}{|c|}{ Initial } & \multicolumn{3}{c|}{ Oversample } & \multicolumn{3}{c|}{ Initial } & Oversample \\
\hline & Median & Max & Min & Median & Max & Min & Median & Max & Min & Median & Max & Min \\
\hline Click through rate (\%) & 6.64 & 21.29 & 2.59 & 4.38 & 10.11 & 1.11 & 1.17 & 6.05 & 0.73 & 1.29 & 3.10 & 0.84 \\
\hline Completion rate (\%) & 1.97 & 7.59 & 0.40 & 0.42 & 2.20 & 0.06 & 0.15 & 2.77 & 0.01 & 0.16 & 0.46 & 0.02 \\
\hline Cost per click (\$) & 0.02 & 0.05 & 0.01 & 0.07 & 0.18 & 0.02 & 0.18 & 0.47 & 0.02 & 0.09 & 0.33 & 0.04 \\
\hline $\begin{array}{l}\text { Cost per completed survey } \\
(\$)\end{array}$ & 0.07 & 0.31 & 0.02 & 0.58 & 4.50 & 0.08 & 1.19 & 22.07 & 0.05 & 0.78 & 8.72 & 0.22 \\
\hline
\end{tabular}

Table 4: Cost of Facebook targeting in Mexico with and without low-education oversample.

\subsection{Variation in costs for specific populations of interest}

Above, we discussed the fact that survey costs can vary dramatically by strata and by the nature of a given survey round. This translates into practical tradeoffs and might create disincentives to target certain populations, and these disincentives can be substantial. Concretely speaking, the difference between the lowest $(\$ 0.05)$ and highest $(\$ 22.07)$ costs we observed per survey for different strata in Kenya would imply that it is cheaper to obtain surveys from 441 men in Nairobi than it is to reach a single female respondent at a specific part of the border between Kenya's Coast and North-Eastern provinces. In Mexico, the highest cost cell was $\$ 4.50$ for women above the age of 60 living in rural Southern Mexico. The lowest cost cell was $\$ 0.02$, by contrast, for men between the ages of 50 and 59 living in rural Northern Mexico.

In Table 5, we present the average cost of targeting different respondent types. For example, to compute the average cost per male respondent, we averaged the cluster-specific cost per response for 


\begin{tabular}{|r|l|l|}
\hline & Mexico FB & Kenya FB \\
\hline Overall & $\$ 0.16$ & $\$ 1.06$ \\
Men & $\$ 0.15$ & $\$ 0.45$ \\
Women & $\$ 0.18$ & $\$ 1.89$ \\
Urban & $\$ 0.12$ & $\$ 0.28^{*}$ \\
Rural & $\$ 0.21$ & $\$ 1.53^{*}$ \\
\hline
\end{tabular}

Note: Afrobarometer sites are classified as rural, urban, or both. When aggregating to $k$-means clusters, we defined "rural" cluster centroids as centroids for which there were more rural than urban Afrobarometer sites ( $n=34)$, and likewise for "urban" $k$-means cluster centroids ( $n=10)$. The calculations ignore Afrobarometer sites which are classified as "both." They also ignore k-means cluster centroids for which an equal number of clusters were rural and urban ( $n=6)$. In the Mexico case, we defined as "rural " those respondents municipalites containing 220,292 residents or fewer, which corresponds to the 1st and 2nd quantiles of municipalities across which the Mexican population is distributed (following our sampling protocol outlined in Appendix Section 2.1).

Table 5: Cost per response for the given respondent type, averaged over all clusters with those respondent types

all clusters containing men. Using this approach, we estimate that Kenyan women are over 4 times more costly to target than Kenyan men, whereas rural respondents are over 5 times more costly to target than urban respondents on average, in Kenya. We do not find such high discrepancies in the cost of contacting men and women in Mexico, and the difference in cost for surveying respondents from small and large municipalies are not as starkly different as in Kenya. 


\section{Survey Instruments}

\subsection{Mexico Survey Instrument}

\section{Introduction}

Hola! Gracias por participar en esta encuesta sobre unos temas políticos. Sabemos que Ud. está ocupado(a) y le agradecemos su participación. Todas sus respuestas serán totalmente anónimas. Para empezar, haga clic en el botón abajo a la derecha de su pantalla.

\section{AmericasBarometer Questions on Climate A}

1. Alguna gente cree que hay que priorizar la protección del medio ambiente sobre el crecimiento económico, mientras otros creen que el crecimiento económico debería priorizarse sobre la protección ambiental. En una escala de 1 a 7 en la que 1 significa que el medio ambiente debe ser la principal prioridad, y 7 significa que el crecimiento económico debe ser la principal prioridad, dónde se ubicaría usted?

- 1

- 2

- 3

- 4

- 5

- 6

- 7

\section{AmericasBarometer Questions on Climate B}

2. Si no se hace nada para reducir el cambio climático en el futuro, qué tan serio piensa usted que sería el problema para México

- Muy serio

- Algo serio

- Poco serio

- Nada serio

\section{Belief in Climate Change}

3. Últimamente, tal vez haya notado que el calentamiento global ha captado la atención de los medios de comunicación. El término "calentamiento global" hace referencia a la idea de que la temperatura mundial promedio ha estado aumentando durante los últimos 150 años, puede aumentar más en el futuro y que el clima del mundo puede cambiar como resultado. Qué piensa?, cree que el calentamiento global existe?

- Sí 
- No

- No lo sé

\section{Follow-up Certainty for Believers}

4. Cuán seguro está de que el calentamiento global existe?

- Para nada seguro

- Medianamente seguro

- Muy seguro

- Extremadamente seguro

\section{Follow-up Certainty for Non-believers}

5. Cuán seguro está de que el calentamiento global no existe?

- Para nada seguro

- Medianamente seguro

- Muy seguro

- Extremadamente seguro

\section{Cause of Climate Change}

6. Suponiendo que el calentamiento global sí existe, qué opina?

- Que es mayormente el resultado de las actividades humanas

- Que es mayormente el resultado de cambios naturales en el medio ambiente

- Otro (especifique)

- Ninguno de los anteriores porque el calentamiento global no existe

\section{Personal importance of climate change}

7. Qué tan importante es el tema del calentamiento global para usted?

- Nada importante

- Poco importante

- Algo importante

- Muy importante

- Sumamente importante 
Personal worry about climate change

8. Qué tan preocupado(a) está usted por el calentamiento global?

- Nada preocupado(a)

- Poco preocupado(a)

- Algo preocupado(a)

- Muy preocupado(a)

\section{Personal impact from climate change}

9. En qué medida cree que el calentamiento global lo perjudicará a usted?

- En nada

- Sólo un poco

- Mucho

- No lo sé

\section{Future generations impact from climate change}

10. En qué medida cree que el calentamiento global perjudicará a las generaciones futuras?

- En nada

- Sólo un poco

- Mucho

- No lo sé

\section{Discussion of global warming with family and friends}

11. Cuánto se esfuerzan su familia y amigos para reducir el calentamiento global?

- Ningún esfuerzo

- Poco esfuerzo

- Un esfuerzo moderado

- Mucho esfuerzo

- Muchísimo esfuerzo

- No lo sé 


\section{Social norms around climate change action}

12. Qué tan importante es para su familia y amigos que usted tome medidas para reducir el calentamiento global?

- No tiene nada de importancia

- No tiene mucha importancia

- Tiene importancia moderada

- Tiene mucha importancia

- Tiene muchísima importancia

- No lo sé

\section{Responsibility for climate action}

13. De la siguiente lista quiénes deben combatir el cambio climático? Nombre todos los que quiera.

- Los países ricos

- Las potencias mundiales

- Todos los ciudadanos

- Los países pobres

- Los gobiernos

- Los organismos internacionales

- Las empresas

- Los científicos

- Las organizaciones ambientalistas

- Yo, mi familia y mis amigos

- Todos

- Nadie

- No lo sé

\section{Scale of climate policy response}

14. Qué tipo de esfuerzo debería hacer México para reducir el calentamiento global?

- Ningún esfuerzo

- Un esfuerzo a pequeña escala, incluso si tiene costos económicos bajos

- Un esfuerzo a mediana escala, incluso si tiene costos económicos moderados

- Un esfuerzo a gran escala, incluso si tiene grandes costos económicos 


\section{Ideology}

15. En política se habla normalmente de izquierda y derecha. En una escala dónde 0 es la izquierda y 10 la derecha, dónde se ubicaría usted?

- 1

- 2

- 3

- 4

- 5

- 6

- 7

- 8

- 9

- 10

\section{Religion}

16. Si usted es de alguna religión, podría decirme cuál es su religión?

- Católico

- Protestante, Protestante Tradicional o Protestante no Evangélico (Cristiano, Calvinista; Luterano; Metodista; Presbiteriano; Discípulo de Cristo; Anglicano; Episcopaliano; Iglesia Morava).

- Religiones Orientales no Cristianas (Islam; Budista; Hinduista; Taoísta; Confucianismo; Bahai)

- Evangélica y Pentecostal (Evangélico, Pentecostal; Iglesia de Dios; Asambleas de Dios; Iglesia Universal del Reino de Dios; Iglesia Cuadrangular; Iglesia de Cristo; Congregación Cristiana; Menonita; Hermanos de Cristo; Iglesia Cristiana Reformada; Carismático no Católico; Luz del Mundo; Bautista; Iglesia del Nazareno; Ejército de Salvación; Adventista; Adventista del Séptimo Día, Sara Nossa Terra).

- Iglesia de los Santos de los últimos Días (Mormones)

- Religiones Tradicionales (Santería, Candomblé, Vudú, Rastafari, Religiones Mayas, Umbanda; María Lonza; Inti, Kardecista, Santo Daime, Esoterica)

- Judío (Ortodoxo, Conservador o Reformado)

- Testigos de Jehová

- Ninguna (Creo en un Ser Superior pero no pertenezco a ninguna religión)

- Agnóstico o ateo (no creo en Dios)

- No lo sé 


\section{Income}

17. En esta tabla hay varios rangos de ingresos Puede decirnos cuál de los siguientes rangos está el ingreso que usted personalmente gana al mes por su trabajo o pensión, sin contar el resto de los ingresos del hogar?[Si no entiende, pregunte: Cuánto gana usted solo, por concepto de salario o pensión, sin contar los ingresos de los demás miembros de su hogar ni las remesas u otros ingresos?] O sea, Cuánto dinero entra en total a su casa al mes?

- Ningún ingreso

- Menos de $\$ 1,600$

- Entre $\$ 1,601$ - $\$ 2,900$

- Entre $\$ 2,901$ - $\$ 4,450$

- Entre $\$ 4,451$ - $\$ 7,050$

- Entre $\$ 7,051$ - $\$ 11,050$

- Más de $\$ 11,051$

\section{Race/Ethnicity}

18. Usted se considera una persona blanca, mestiza, indígena, negra, mulata, u otra?

- Blanca

- Mestiza

- Indígena

- Negra

- Mulata

- Otra

\section{Age}

19. Cuál es su edad en años cumplidos?

\section{Gender}

20. Cuál es su género?

- Hombre

- Mujer

- Otro

\section{Place of Residence}

21. Cuál es su ...

- estado de residencia? [DROP-DOWN MENU]

- municipio de residencia? [DROP-DOWN MENU FOR SELECTED STATE] 


\section{Education}

22. Cuál fue el último año o grado de educación que usted completó o aprobó?

- Ninguno

- Primaria

- Secundaria

- Bachillerato/Profesional Técnico/Media Superior

- Universitaria

- Superior de Universitaria

\section{Marital Status}

23. Actualmente...

- Vive con su pareja en unión libre?

- Está separado(a)?

- Está divorciado(a)?

- Está viudo(a)?

- Está casado(a)?

- Está soltero(a)? 
The survey used in Mexico contained 14 substantive questions and 9 demographic questions. It replicated certain questions from the Mexican Census and the LAPOP survey, fielded in early 2019 (LAPOP 2018-2019). The attitude questions were largely focused on measuring beliefs about climate change. Climate change is a global problem, which will require coordination across countries to solve, including popular political support in many countries. The issue of climate change thus offers an important empirical setting in which to explore the potential for Facebook to generate inexpensive but accurate estimates of cross-national opinions, including in countries across the Global South. In order to avoid biasing the sample, our Facebook advertisements did not mention climate change, but instead invited respondents to provide their opinion on an unspecified issue.

\subsection{Kenya Survey Instrument}

The survey fielded in Kenya contained 60 questions which collected information on demographic characteristics, mobility and geographic location, political attitudes and engagement, news consumption and social media use, household assets and living conditions, and other topics. Several of the questions about demographics, political attitudes, media use, and household assets were drawn from the 2016 (Round 7) Afrobarometer survey.

The Kenyan survey also included a replication of Tversky and Kahneman's (1981) "disease problem" - which has been conducted in a wide range of contexts over time. This question asks respondents:

Imagine that your country is preparing for the outbreak of an unusual disease, which is expected to kill 600 people. Two alternative programs to combat the disease have been proposed. Assume that the exact scientific estimates of the consequences of the programs are as follows.

Then respondents are presented with two policy options: a single certain option, and a risky option that assigns probabilities to two different outcomes. In expectation, the payoffs of both policies are equal, so differences in respondents' choices should be driven primarily by their appetites for risk. Respondents are randomly assigned to one of two conditions: either the policy options are framed in terms of a loss (number of deaths) or the policy options are framed as a gain (number of lives saved). The canonical finding that has been replicated in many samples across the globe suggests that people are loss averse - favoring the certain option when it is framed in terms of lives saved, and the risky option when it is framed in terms of lives lost (Tversky and Kahneman 1981).

We fielded our survey on Facebook immediately following the 2019 census and concurrent with the 2019 Afrobarometer in order to ensure that observed differences between our survey and nationally representative samples would not result from differences in timing. ${ }^{9}$

1. In which language would you like to conduct the survey?

[English, Swahili, Kikuyu, Luo, Somali]

2. In which county do you live?

[drop down list]

\footnotetext{
${ }^{9}$ Note: the 2019 Afrobarometer data are not yet available, so we currently compare our sample to the 2016 Afrobarometer.
} 
3. Which town or city do you live closest to? [drop down list]

4. How long would it take you to drive by motorbike to [city/town]?

5. How would you describe the area or neighborhood in which you live?

[Completely urban, mostly urban, mixed, mostly rural, completely rural]

6. In which county do you work?

[drop down list]

7. In which county do you spend most of your time?

[drop down list]

8. In which county are you now?

[drop down list]

9. When you get together with your friends or family, how often would you say you discuss political matters?

10. In this country, how free are you to say what you think?

11. In your opinion, what are the three most important problems facing this country that government should address?

12. Of the most important problems you chose in the last question, please rank them as most important (1st) to least important (3rd).

13. Let's talk about your general view about the current direction of our country. Overall when you think about Kenya today, would you say that the country is going in the right direction or going in the wrong direction?

[Going in the right direction / neither right nor wrong direction / going in the wrong direction]

14. Lets talk for a moment about the kind of society you would like to have in this country. Which of the following statements is closest to your view?

- Statement 1: Men make better political leaders than women, and should be elected rather than women.

- Statement 2: Women should have the same chance of being elected to political office as men.

[Agree very strongly with statement 1, agree with statement 1, agree with statement 2, agree very strongly with statement 2]

15. Do you approve or disapprove of the way President Uhuru Kenyatta is handling his job as president of Kenya?

[Strongly approve, somewhat approve, neither approve nor disapprove, somewhat disapprove, strongly disapprove]

16. (Attention check) We are interested in how people conceive of democracy. We also want to know if people pay attention to survey questions. To show you are paying attention, please answer the question below and put the letter " $k$ " in the blank space next to the "other" response. That's right, please select your real answers and put " $k$ " in the "other" response. What if anything does "democracy" mean to you? 
17. ( $\mathrm{T} \& \mathrm{~K}$ disease experiment) Imagine that your country is preparing for the outbreak of an unusual disease, which is expected to kill 600 people. Two alternative programs to combat the disease have been proposed. Assume that the exact scientific estimates of the consequences of the programs are as follows:

- If Program A is adopted, [200 people will be saved / 400 people will die].

- If Program B is adopted, [there is $1 / 3$ probability that 600 people will be saved, and a $2 / 3$ probability that no people will be saved. / there is a $1 / 3$ probability that nobody will die, and a $2 / 3$ probability that 600 people will die.]

Which of the two programs do you prefer?

18. Here is a list of actions that people sometimes take as citizens. For each of these, please tell me whether you, personally, have done any of these things during the past year:

- Attended a community meeting

- Got together with others to raise an issue

- Joined others in your community to request action from government

- Contacted a government official to ask for help or make a complaint

- Participated in a demonstration or protest march.

[Yes, often / Yes, several times / Yes, once or twice / No, but would if had the chance / No, would never do this]

19. Understanding that some people were unable to vote in the most recent national election in 2017, which of the following statements is true for you?

[I did not vote / I voted]

$20 . \stackrel{\text { If no }}{\longrightarrow}$ Why did you not vote in the 2017 elections?

[Could not find my name in the register / was not registered / decided not to vote / was too young to vote / could not find polling stationn / did not have time / other]

21. Do you feel close to any particular political party?

[Yes/No]

22. $\stackrel{\text { If yes }}{\longrightarrow}$ Which party is that?

23. What is your gender?

24. What is your highest level of education?

25. What is your religion, if any?

26. How many people are in your household?

27. Are you the head of your household?

28. What is your relationship to the head of your household?

29. What is your current marital status?

30. Do you have any children? If so, how many? 
31. How old is your youngest child?

32. How many people did you share food or drink with yesterday?

33. How many of these people who you shared food or drink with yesterday are women?

34. How many of these [\#] women have their own Facebook profile?

35. For the purposes of the next few questions, we want you to think about women that you know who live in Kenya. How many women do you know that had a child in the last 12 months?

36. How many of these women have a Facebook profile?

37. How many women do you know that have a child who is in between 1 and 2 years old?

38. How many of these women have a Facebook profile?

39. How many women do you know that have a child who is in between 3 and 5 years old?

40. How many of these women have a Facebook profile?

41. How often do you use Facebook, Twitter, Whatsapp, Instagram ? [Never / less than once a month / a few times a month / a few times a week / every day]

42. How often do you get news from the following sources: Radio, television, the Internet, social media (such as Facebook and Twitter)? [Never / less than once a month / a few times a month / a few times a week / every day]

43. Please tell me how much you trust each of the following sources of information: What you hear on the radio? What you read on social media such as WhatsApp, Instagram, and Facebook?

44. (Attention check) Which of these things do you or anyone in your household own? (Radio, television, motor vehicle or motorcycle, computer/laptop, bank account, submarine, mobile phone, bicycle, Facebook account)

45. Do you personally own the phone you use?

46. Who owns the phone you use?

47. Does anyone else use this phone as their primary phone?

48. Who else uses this phone as their primary phone number?

49. Please tell me whether each of the following are available inside your house, inside your compound, or outside your compound: Your main source of water for household use? A toilet or latrine?

50. Do you have an electric connection to your home from the mains (the main electrical grid, for example Kenya Power)?

51. How often is electricity actually available from this connection?

52. Do you have a job that pays a cash income? Is it full time or part time?

53. Are you presently looking for a job? 
54. Over the past year, how often, if ever, have you or anyone in your family: Gone without enough food to eat? Gone without enough clean water for home use? Gone without a cash income?

55. What is your ethnic community, cultural group or tribe?

56. Let us suppose that you had to choose between being a Kenyan and being a [tribe], which of the following statements best expresses your feelings? [I feel only Kenyan $\longleftrightarrow$ I feel only [tribe]]

57. (Attention check) To confirm you are paying attention to the survey questions, please tell us again what is your age?

58. Would it be okay if we contacted you in the future for other surveys?

59. Have you ever been surveyed before?

60. Have you ever taken an online survey before on Facebook?

\section{$5 \quad$ Weighting}

For both samples, we then used iterative proportional fitting, or raking, to create weights for all respondents according to the distribution of the national populations across gender, education, age cohort, and geography. In Kenya we collated the marginal distributions of Kenyans age 18 years and older in the population using the 2019 census data for the following categories: age (18-29, 30-49, 50-59, 60+), gender (male/female), education (primary or less, secondary, technical training, university or above), and geography (urban/rural) (KNBS 2010). In Mexico we used the same age and gender categories as in Kenya, education (none, secondary or less, technical training, university or above), and geography (size of municipality within the four regions of the country) (INEGI 2015). In both cases, we trimmed weights by setting the minimum weight to the 5th percentile and the maximum weight to the 95 th percentile. ${ }^{10}$

\footnotetext{
${ }^{10}$ In Mexico, 512 individuals (9.9\% of the sample) had untrimmed weights falling outside this range (0.1-4.6) and were adjusted. In Kenya 67 observations ( $5 \%$ of the sample) had original weights outside of this range (0.7-2.5) and were adjusted.
} 


\section{References}

Berinsky, Adam J., Michele F. Margolis, and Michael W. Sances (2014). "Separating the Shirkers from the Workers? Making Sure Respondents Pay Attention on Self-Administered Surveys". In: American Journal of Political Science 58.3, pp. 739-753. ISSN: 1540-5907. DOI: 10.1111/ajps. 12081.

Berinsky, Adam J., Michele F. Margolis, Michael W. Sances, and Christopher Warshaw (2019). "Using screeners to measure respondent attention on self-administered surveys: Which items and how many?" In: Political Science Research and Methods, pp. 1-8. ISSN: 2049-8470, 20498489. DOI: $10.1017 / \mathrm{psrm} .2019 .53$.

Iarossi, Giuseppe (2006). The power of survey design: A user's guide for managing surveys, interpreting results, and influencing respondents. The World Bank.

INEGI (2015). Population. Accessed: 20 August, 2019. uRL: http://en . www. inegi .org.mx/ temas/estructura/default.html\#Tabulados.

KNBS (2010). 2019 Population and Housing Census. Accessed: 9 June, 2020. URL: http://www . knbs.or.ke.

LAPOP (2018-2019). Mexico. Accessed: 16 October, 2019. URL: https://www .vanderbilt.edu/ lapop/mexico.php.

Latin American Public Opinion Project (2017). Americas Barometer, 2016/17. urL: https://www . vanderbilt.edu/lapop/ab2016/AmericasBarometer_2016-17_Sample_Design.pdf.

Lumley, Thomas (2020). survey: analysis of complex survey samples. $\mathrm{R}$ package version 4.0.

Tversky, Amos and Daniel Kahneman (1981). "The framing of decisions and the psychology of choice". In: Science 211.4481, pp. 453-458. 